UCRL-ID-131210

\title{
National Ignition Facility Wet Weather Construction Plan
}

August N. Kugler

January 1998

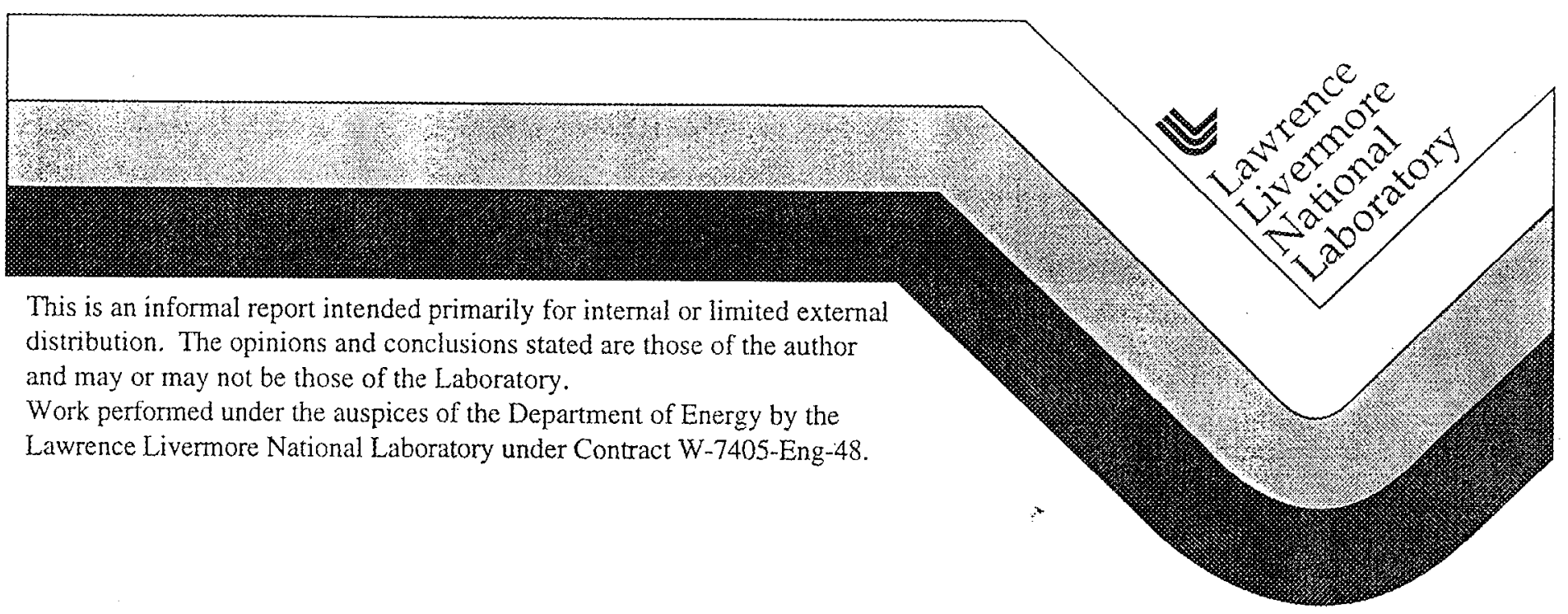




\section{DISCLAIMER}

This document was prepared as an account of work sponsored by an agency of the United States Government. Neither the United States Government nor the University of California nor any of their employees, makes any warranty, express or implied, or assumes any legal liability or responsibility for the accuracy, completeness, or usefulness of any information, apparatus, product, or process disclosed, or represents that its use would not infringe privately owned rights. Reference herein to any specific commercial product, process, or service by trade name, trademark, manufacturer, or otherwise, does not necessarily constitute or imply its endorsement, recommendation, or favoring by the United States Government or the University of California. The views and opinions of authors expressed herein do not necessarily state or reflect those of the United States Government or the University of California, and shall not be used for advertising or product endorsement purposes.

This report has been reproduced directly from the best available copy.

Available to DOE and DOE contractors from the Office of Scientific and Technical Information

P.O. Box 62, Oak Ridge, TN 37831

Prices available from (615) 576-8401, FTS 626-8401

Available to the public from the

National Technical Information Service

U.S. Department of Commerce

5285 Port Royal Rd.,

Springfield, VA 22161 
Engineering Report

\section{National Ignition Facility}

Wet Weather Construction Plan

Prepared for:

Lawrence Livermore National Laboratory

Livermore, CA

Prepared by:

Earth Tech, Inc.

10800 N.E. 8 th Street, 7th Floor

Bellevue, WA 98004

January 1998 
January 16,1998

Mr. August N. Kugler, NIF Conventional Facilities Site Manager

Lawrence Livermore National Laboratory

7000 East Avenue

Livermore, California 94550

\section{Subject: National Ignition Facility \\ Wet Weather Construction Plan \\ Final Report}

Dear Mr. Kugler:

We are pleased to submit the enclosed copies of the final report presenting the Wet Weather Construction Plan developed for the National Ignition Facility on the Lawrence Livermore National Laboratory site. This report documents observed site conditions and the strategy, techniques and management practices recommended by Earth Tech and implemented by the NIF construction team to allow construction to proceed throughout the wet weather season. The core design information presented in this report was provided directly to the NIF construction team during our site visits for immediate implementation.

We are pleased that we were able to react to your request for quick action and commend your organization for its responsiveness to our recommendations. Your immediate response and rapid implementation of the recommended remedial and protective measures has provided you with an opportunity to bring the project back into schedule compliance.

We recognize the importance of maintaining the construction schedule on the NIF project, and Earth Tech is pleased to have had this opportunity to support you and your team. Please call us if we can be of further assistance.

Very truly yours,

Earth Tech, Inc.

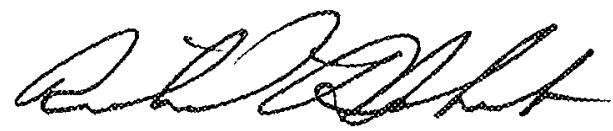

Gary R. Bourne, P.E.

Senior Vice President, Regional Manager

Enclosures 


\section{National Ignition Facility}

Wet Weather Construction Plan

Prepared for:

Lawrence Livermore National Laboratory

Livermore, $\mathrm{CA}$

Prepared by:

Earth Tech, Inc.

10800 N.E. 8th Street, 7th Floor

Bellevre, WA 98004

January 1998 


\section{Table of Contents}

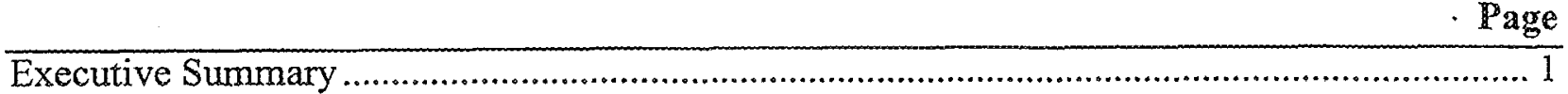

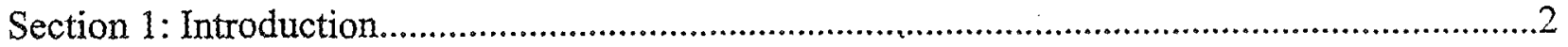

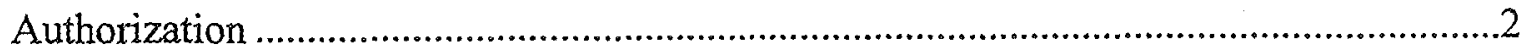

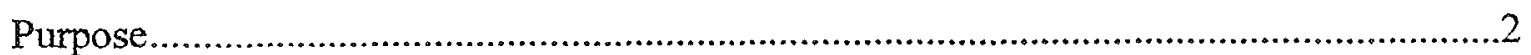

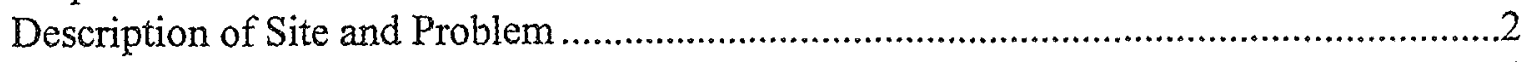

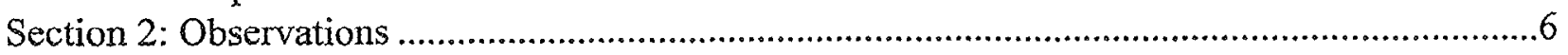

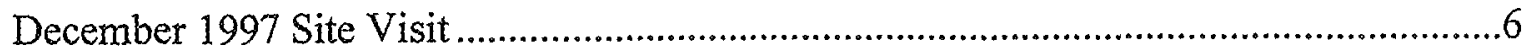

January 1998 Site Visit .................................................................................

Section 3: Wet Weather Protection Strategy .................................................................14

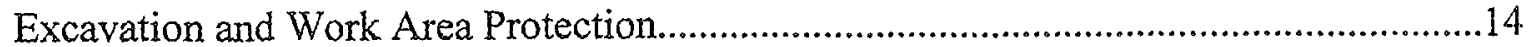

Access Road Stabilization..................................................................................19

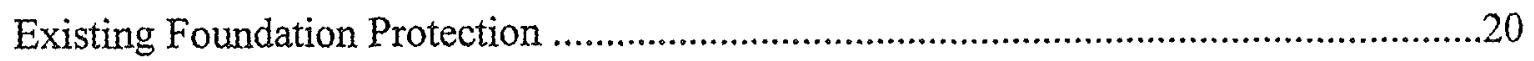

Other Considered Strategies ..............................................................................20

Section 4: Design Criteria and Sizing of Controls............................................................22

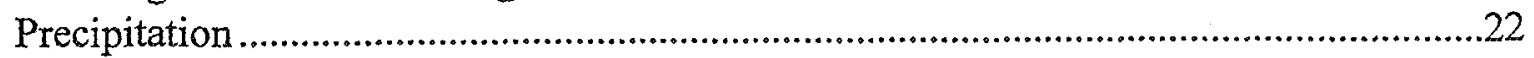

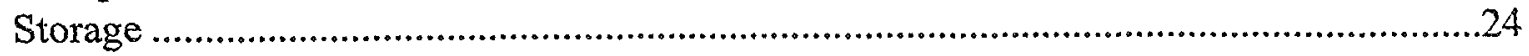

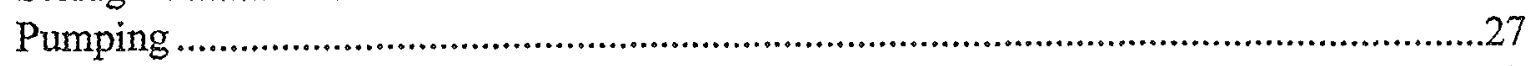

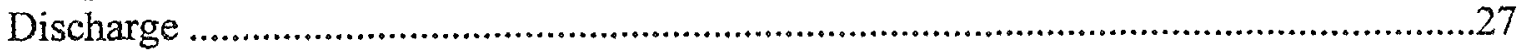

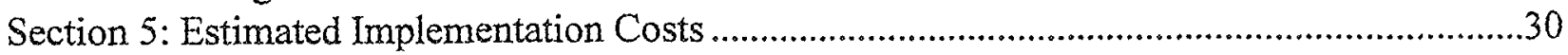

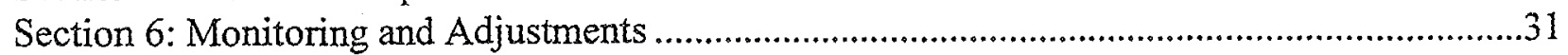

\section{Apperaices}

Appendix A Bibliography

Appendix B Excerpts from Draft Stormwater Best Management Practices Guidebook, Boise City

Appendix C Selected Calculations

Appendix D Resumes of Key Personnel 


\section{List of Tables}

Page

Table 1. Estimated Unit Costs for Alternative Surfacings...........................................................21

Table 2. 10-Year Storm Precipitation Depths, Berkeley, CA ......................................................23

Table 3. 10-Year Storm Precipitation Depths, Berkley and Livermore, CA ……........................23

Table 4. Recommended Dike Heights and Pump Capacities......................................................25

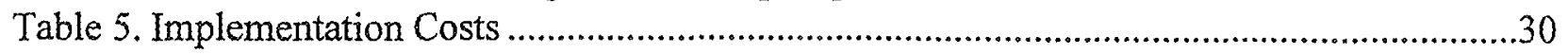

\section{List of Figures}

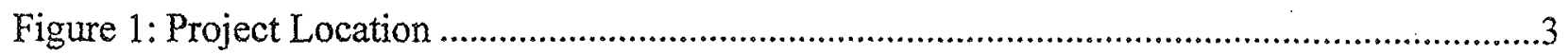

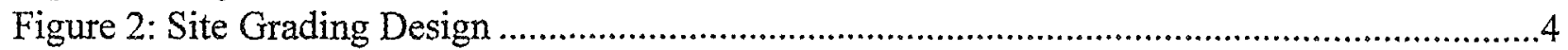

Figure 3: 10-Year Frequency/24-Hour Duration Design Storm Hyetograph ..............................26

Figure 4: Location of Storage and Pumping Facilities ..........................................................28

Figure 5: Storage and Pumping Configuration .........................................................................29 


\section{Executive Summary}

\section{EXECUTIVE SUMMARY}

Intense rainfall events in late November caused water-related damage and delays to construction of the National Ignition Facility at the Lawrence Livermore National Laboratory. Softened subgrades, eroded slopes and ponded water within a large excavation interfered with progress in placing concrete for retaining walls and slabs. Personnel from Earth Tech, Inc. were contracted to advise on measures to remediate the site and to prepare this Wet Weather Construction Plan for the project.

The Wet Weather Construction Plan recommends a strategy, techniques and management practices to prepare and protect the construction site from wet weather effects and allow construction to proceed. It is intended that the information presented in this plan be incorporated, as appropriate, in the project's Stormwater Pollution Prevention Plan.

An initial site visit was conducted over the week of December 1 through 5, 1997. Surficial soils within the completed excavation were soft with flowing mud extending to a depth of from 4 to 10 inches due to saturation and disturbance by vehicular and foot traffic. Slopes were eroded in places by concentrated storm runoff flowing over the slopes. Surface drainage in and around the excavation was blocked and erratically channeled by vehicle rutting. Pumps were being used to lift collected water out of the excavation to disposal areas located at the site perimeter.

During the initial site visit, Earth Tech personnel developed a control strategy and forwarded initial recommendations to remediate existing damage to the site. Preliminary recommendations were presented verbally and in drawing form to site construction personnel and to management during the week. Construction management staff moved forward with our recommendations immediately and implemented control measures rapidly. By the end of the week, working slabs were placed throughout the target bay and switchyard areas and pumps were placed in strategic locations; this work represented the most critical elements of the remediation strategy and provided a clean work area for immediate construction tasks. This rapid implementation was accomplished through timely decision-making and round-the-clock coordination of contractors, equipment and material.

Further consultation regarding access road stabilization and other topics was provided over the phone to construction management staff over the following weeks, and a draft plan document was submitted for review in mid-December. A second site was conducted January 6 and 7, 1998 to review progress, refine the initial recommendations and advance the wet weather control strategy to future stages of construction. 


\section{AUTHORIZATION}

Preparation of this report by Earth Tech, Inc., was authorized by the Regents of the University of California Lawrence Livermore National Laboratory under Subcontract No. B344788, executed on November 25,1997, which is a subcontract under the University's prime Contract No. W-7405-ENG-48 with the Department of Energy.

\section{PURPOSE}

This report presents a wet weather construction plan for the National Ignition Facility (NIF) construction project. Construction of the NIF commenced in mid-1997, and excavation of the site was completed in the fall. Preparations for placing concrete foundations began in the fall, and above normal rainfall is expected over the winter. Heavy rainfall in late November impacted foundation construction, and a wet weather construction plan was determined to be needed. This wet weather construction plan recommends a strategy, techniques and management practices to prepare and protect the site from wet weather effects and allow construction work to proceed. It is intended that information in this plan be incorporated in the Stormwater Pollution Prevention Plan (SWPPP) as warranted.

\section{DESCRIPTION OF SITE AND PROBLEM}

The NIF is being constructed for the Department of Energy at the Lawrence Livermore National Laboratory in Livermore, California. The project location is shown in Figure 1. The facility is approximately 800 feet (east-west) by 400 feet (north-south) in plan with a maximum excavation depth below grade of 50 feet.

Earth Tech staff first arrived on the project site December 1, 1997. The mass excavation was complete, and the excavation pads were compacted to final grade for concrete placement. Figure 2 shows the design excavation grades for the facility. Installation of reinforcing steel for a retaining wall footing was underway, and construction of foundations, retaining walls and base mats is scheduled to proceed through the winter to maintain the project's construction schedule.

Intense rainfall in late November 1997 created erosion, sediment deposition and soft ground conditions within the excavation which have slowed progress in constructing a large retaining wall in the deepest portion of the excavation. Although the tallest slopes in the excavation were protected by a fiber mat curtain, rainfall runoff had eroded exposed slopes in the excavation interior and deposited sediment on construction pads and most notably below the reinforcing steel placed for the retaining wall footing. Compacted pad grades had been softened by ponded runoff rendering them unsuitable for founding concrete placement and requiring remediation and a delay of concrete placement. 
Earth Tech staff were requested to consult with and provide guidance to the Owner's project construction management personnel on methods to remediate water-related conditions within the excavation and to protect the site from similar wet weather problems in the future. Verbal consultations were provided throughout the week of December 1 to 5 , and preliminary facility sizing recommendations were presented. 


\section{Section 2: Observations}

\section{DECEMBER $199 \%$ SITE VISIT}

Earth Tech staff visited the site and met with project and construction management personnel daily throughout the week of December 1 through 5, 1997. The site is characterized as a large, multi-level excavation with relatively flat surrounding topography. The excavated area was near grade across the east half (laser bays), and was progressively deeper towards the west end of the building where it is approximately 50 feet below grade at the Target Bay surrounding the target chamber. A second deep excavation was located at the far east end to found the Optics Assembly Building. Photograph 1 provides a view of the excavation prior to onset of wet weather.

There was evidence of limited surface runoff entering the excavation from the surrounding site, but the primary source of water appeared to be heavy rainfall directly on the excavation footprint itself which had ruined most of the prepared grading. The wet weather season had only just commenced and was expected to be a continuing problem through March and possibly into April. The scheduling impacts of delayed foundation work through the winter are very serious, as several contracts for subsequent work have been awarded with firm milestone dates. The schedule relies upon continued construction progress through the winter.

The soil within the excavation was fairly erodable. Slope protection in the form of fiber matting had been draped on the taller slopes around the excavation perimeter and seemed to be effective is preventing erosion, but intermediate slopes separating pad grades within the excavation were only partially protected. These intermediate slopes were eroded along concentrated flow paths, and sediment was deposited on the grades below (refer to Photographs 2,3 and 4). There was evidence of washout under the comer of one of the laser bay footings, and some soil walls separating adjacent excavations within the laser bays were breached when overtopped by collected runoff.

The slope above an access road to the south switchyard that had been freshly graded into the south side of the excavation contained a dark colored lens of soil that appeared to be wet and indicated the possibility of seepage. We recommend the geotechnical engineer review this and any similar soils for the presence of seepage and potential for reduced slope stability.

The graded surfaces were softened from runoff saturation and construction disturbance. The surficial soils contain relatively high silt and clay contents. When wetted and disturbed, the texture of the soils became fairly plastic and slick. It was noted that the softened condition typically extended to a depth of 4 to 10 inches and that the subgrade appeared to retain its strength. The subgrade condition was periodically tested and reviewed by the geotechnical engineer during Earth Tech's reconnaissance. While Earth Tech personnel did not perform tests of the soil materials, our experience with similar types of soils would indicate that the soil is not expansive and would be expected to stabilize in-situ upon drying if left undisturbed. 
1. Target Bay Excavation (Looking East) Prior to Weather.

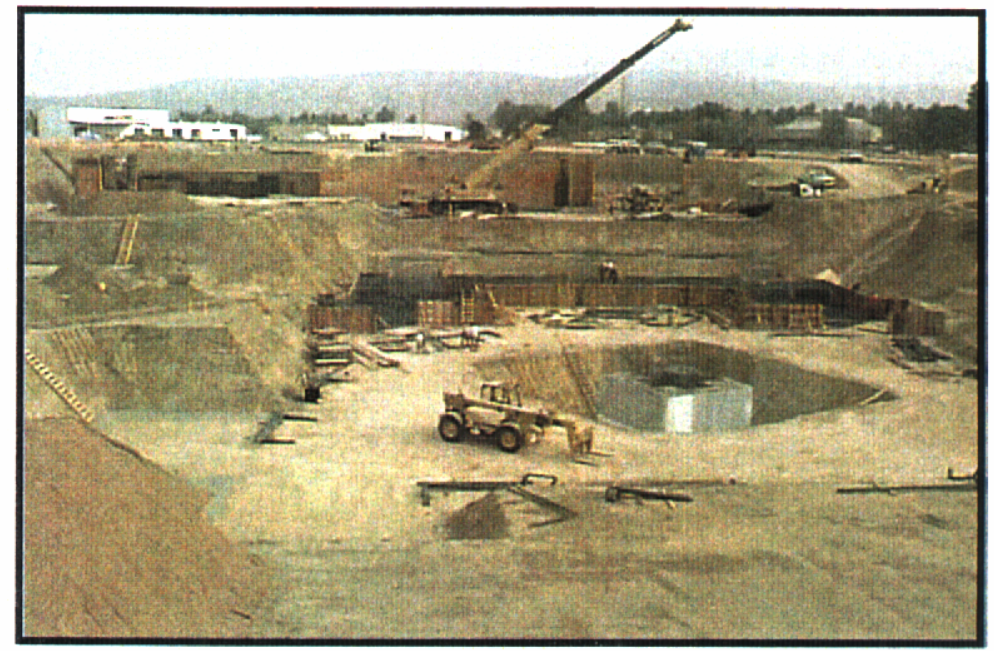




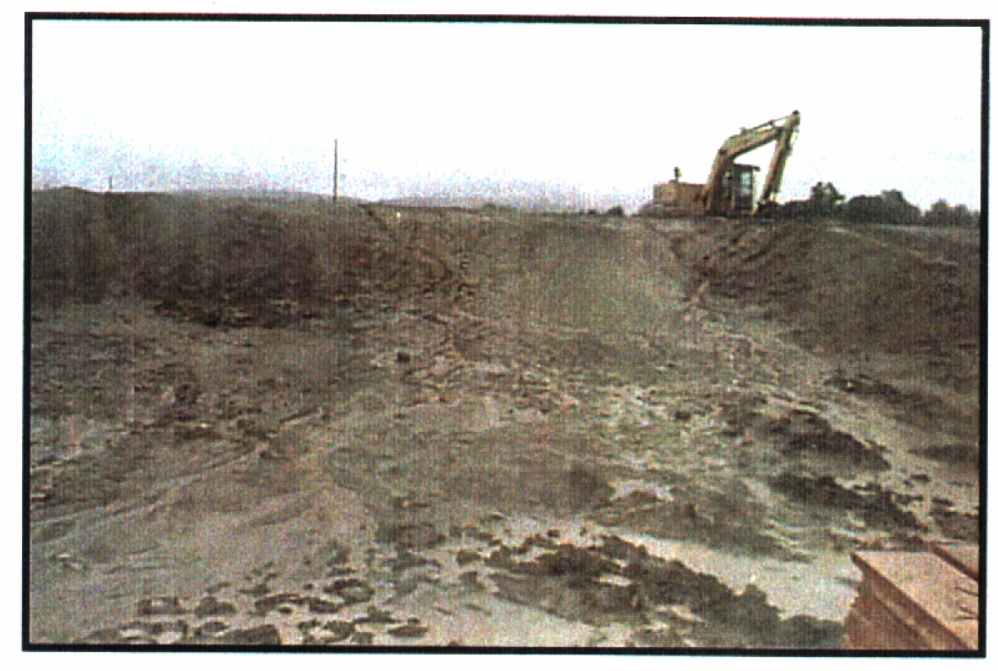

2. Eroded Construction Ramp into Excavation.

3. Slope Eroded by Surface Flows Entering Excavation.
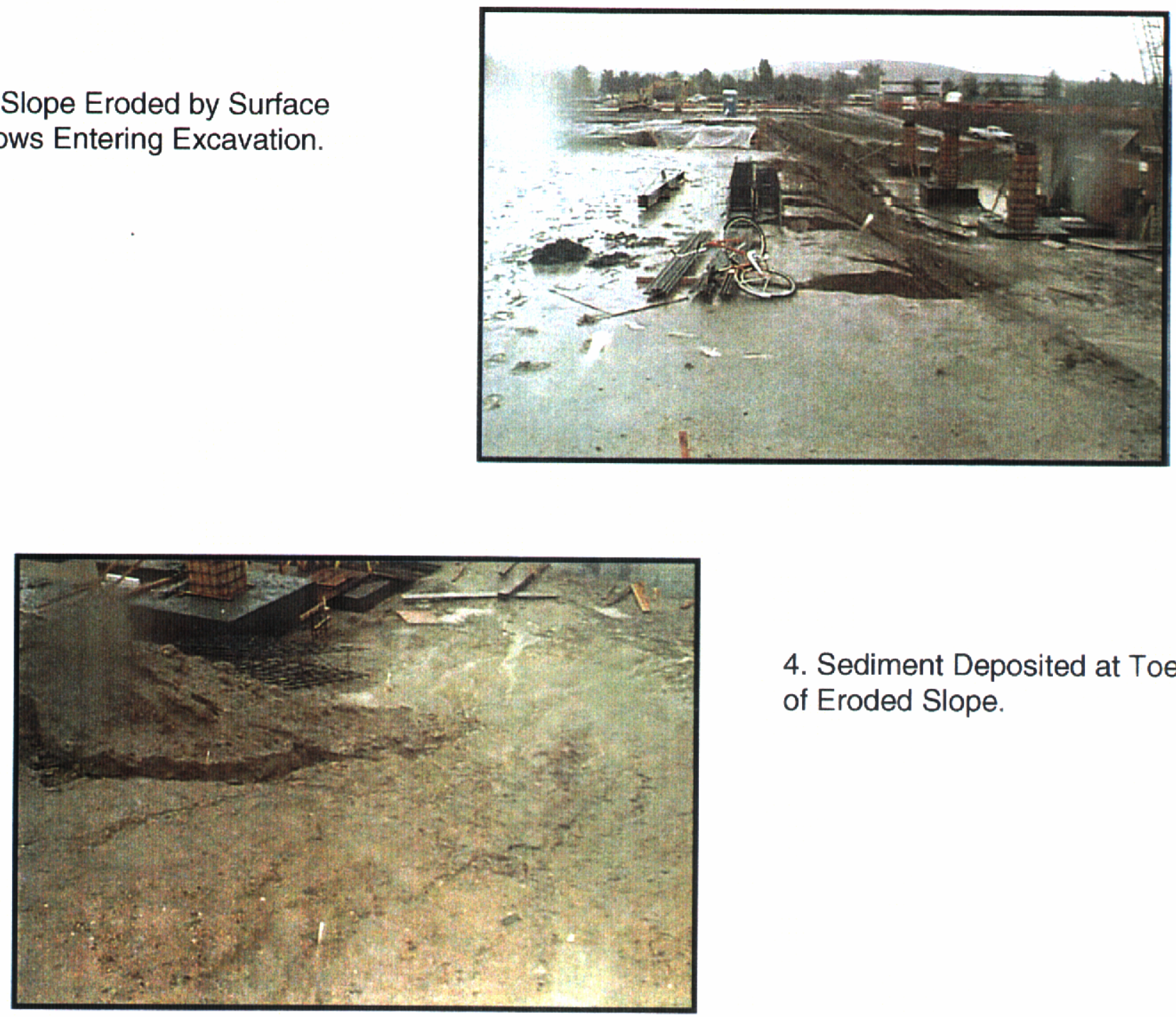

4. Sediment Deposited at Toe of Eroded Slope. 
There were substantial quantities of standing water within and surrounding the excavation from recent rainfall events, and much of the previously prepared subgrade had been chewed up by traffic (refer to Photographs 5,6 and 7). Surface drainage was essentially blocked and flow paths had been erratically channeled by vehicle rutting. Small sumps, using perforated pails set into the grade, were used for setting construction pumps to lift collected water out of the excavation to disposal ponds located at the site perimeter (refer to Photographs 8 and 9).

Water pumped out of the excavation was being discharged to shallow basins surrounding storm sewer catch basins. The catch basin inlet grates were fitted with filter fabric to restrict the entry of suspended solids to the storm sewers. Many of these filter fabric assemblies had been covered by sediment which would, during a storm event, result in surcharging of the inlet and in flows bypassing the filter fabric through the vertical curb face opening. The basin surrounding Catch Basin 7 north of the excavation had very little freeboard above the top of the catch basin inlet, and surcharging of this basin would result in water breaching the top of a slope and entering a parking lot below.

Some concrete had been placed within the excavation. Prior concrete placement included tunnel walls which run north-to-south through the middle of the structure; some of the footings for the north and south walls of the laser bays; and a working slab ("rat slab") surrounding the target chamber within the target bay immediately surrounding the target chamber. Various trenches with partial conduit installation were in various stages of completion in the north and south switchyard pads.

Reinforcing steel was placed, tied and partially sheltered under plastic tents at the north-south retaining wall-pilaster structure at the east end of the target bay. Recent rainfall had deposited water and sediment onto the subgrade underlying the retaining wall foundation and softened the soils (refer to Photograph 10). The placed reinforcing steel had settled due to softening subgrade and collapse of some chairs (refer to Photograph 11). Settlement ranged from 1 to 2 inches in some locations and from 3 to 4 inches in others. Alternative strategies to repair the foundation subgrade were under consideration by the construction management team.

Recent rainfall intensities reported by the construction management team included 1 inch of rainfall within 1.5 hours approximately two weeks during the week of November 17 and $3 / 8$ inch of rainfall overnight between November 28-29.

\section{JANUARY 1998 SITE VISIT}

Earth Tech staff visited the site and met with project and construction management personnel on January 6 and 7, 1998. Most of the wet weather construction recommendations made during and immediately following the December site visit had been implemented prior to the January visit. The recommendations appeared to have had the intended beneficial effect on construction productivity: 
- The target bay and the north and south switchyards were paved with a lean concrete rat slab. The slab areas were clean of debris, materials were stored on the slabs, and equipment was operating unimpeded by ground conditions.

- The target bay retaining wall foundation had been poured and forms for the retaining wall itself were being erected.

- A ramp was being cut through the south slope into the south switchyard, and this ramp was planned to be paved with concrete to provide a durable travel surface over its intended 6-month service life.

- Runoff from the switchyards, diagnostics pad and target bay were being contained by dikes and drained to the ramming pit in the target bay floor and then pumped outside of the excavation for disposal. The ramming pit was equipped with two large (4-inch diameter discharge) pumps operated by generators and float switches.

- The laser bays had been graded to drain to their centers, away from footings located at their perimeters. The surfaces of the laser bays and the intervening elevated subgrade had been stabilized by scarifying and recompacting the upper 12 inches of soil with a hydrated lime additive. These areas were well drained and sufficiently hard to resist disturbance by foot traffic and light vehicles. Runoff from the laser bays was being pumped to the cooling tower pad for treatment prior to discharge. The $\mathrm{pH}$ of the stored water was to be tested prior to release to the storm drainage system.

- The access road surrounding the excavation had been stabilized with the hydrated lime additive and then surfaced with gravel. A large staging area at the southeast corner of the site had been similarly stabilized. The road surfaces appeared stable under the traffic of heavy equipment.

- The catchments surrounding the storm drain inlets had been cleaned and protected with a combination of gravel, straw bales and filter fabric.

- Treatment basins had been constructed around the site perimeter to receive runoff from the excavation. The basin in the northwest comer of the site was divided into two independent cells to enhance treatment and operational flexibility.

- Areas surrounding the excavation had been graded to drain away from the top of the slopes.

The site had received approximately 1.5 inches of rainfall over the January $3-4$, with a peak intensity of 0.3 inches per hour. A smaller rainfall event also occurred the evening of January 6 . Despite the precipitation, the site was in good condition and construction proceeded. 


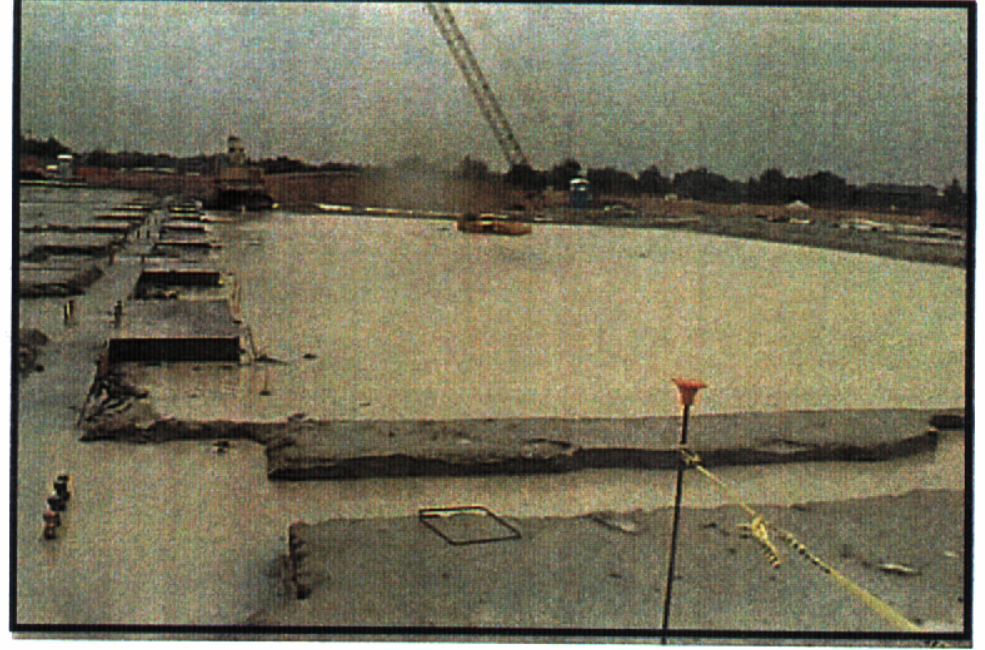

5. Standing Water in Laser Bay Following November Storm.

6. Saturated Ground in Capacitor Pad in November.
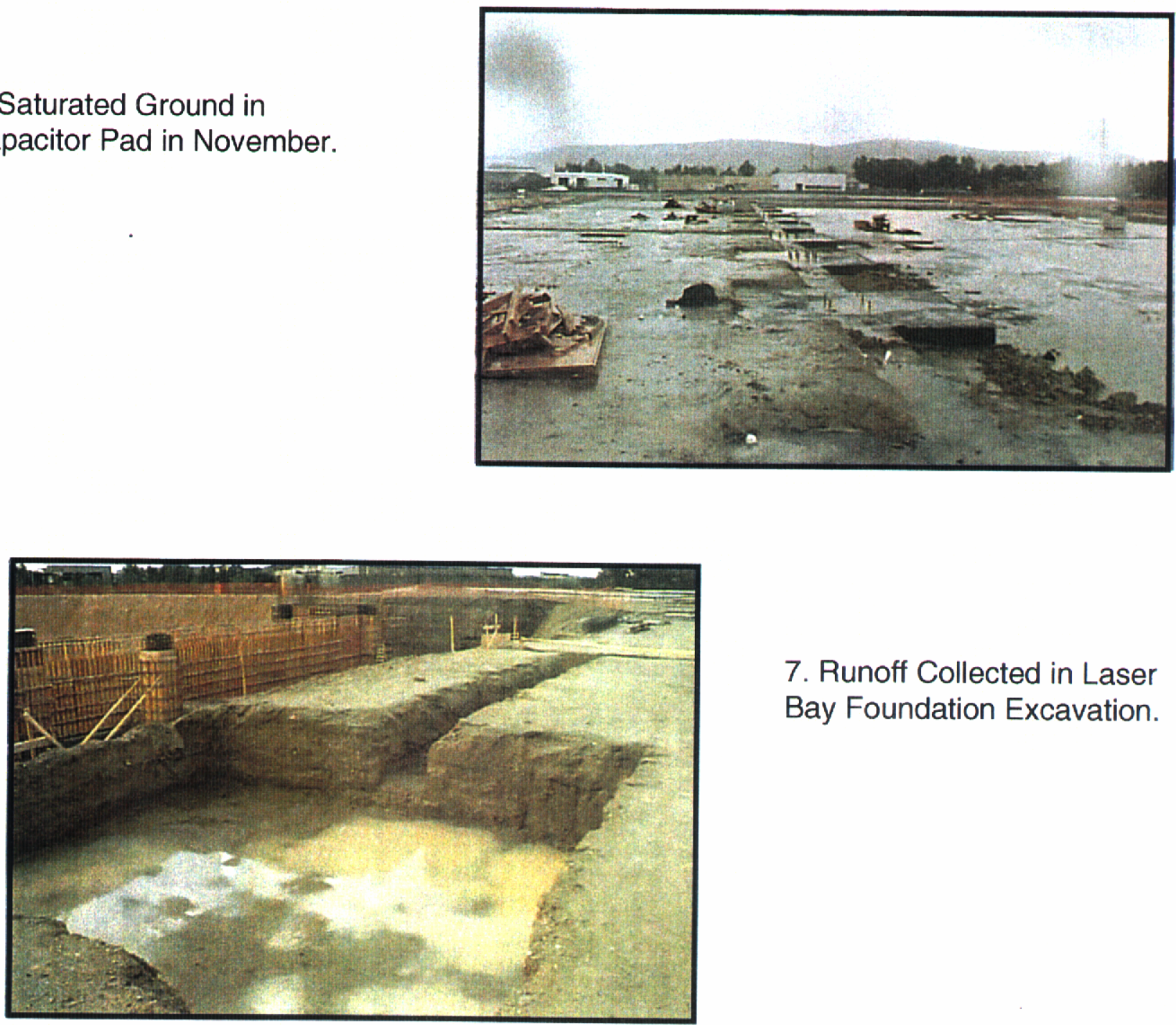

7. Runoff Collected in Laser Bay Foundation Excavation. 


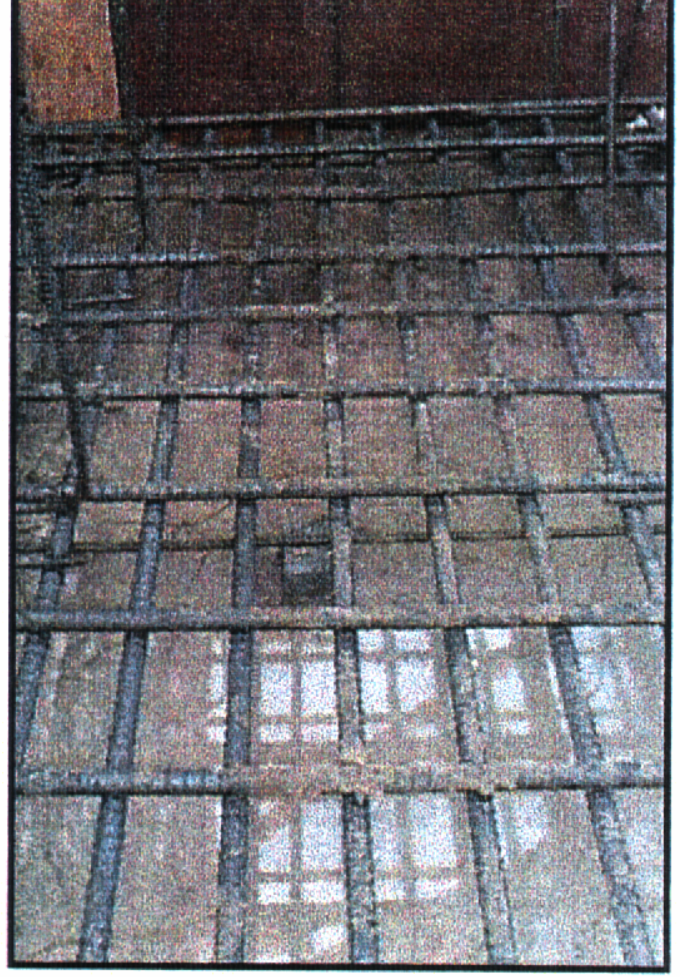

10. Standing Water on

Subgrade for Target Bay

Retaining Wall Foundation.

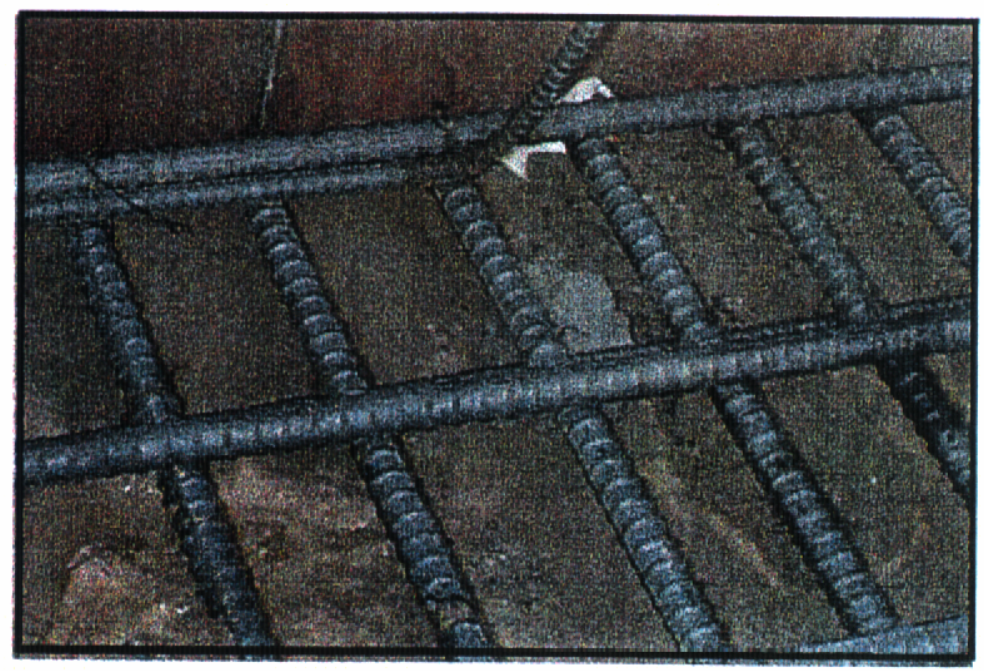

11. Settled Chairs Supporting Reinforcing Steel for Target Bay Retaining Wall Foundation. 


\section{Section 3: Wet Weather Protection Strategy}

The wet weather protection strategy developed for the site is composed of several elements and are designed to limit the volume of water that must be controlled, limit the concentration of water at any one point in the excavation, prevent collected water from damaging grades, and control the quality of water discharged from the site in compliance with the Storm Water Pollution Prevention Plan (Specification OCS-0068, CSP-2). These elements consist of Best Management Practices (BMPs) that are designed to prevent water related damage to the site that would delay construction and prioritize protection of those areas of the site to be worked on soonest. Following are descriptions of the various elements of the strategy; included in the descriptions are references to BMPs identified in the SWPPP.

\section{EXCAVATION ANO WORK AREA PROTECTION}

- Prevent water from entering the excavation from the surface grade. Grade the surrounding surfaces and construct ditches or berms around the perimeter to direct water away from the edge of the excavation. This practice will reduce the scale of the erosion, sediment deposition and subgrade saturation within the work area. It will also limit the amount of pumping required to remove water from the excavation. Refer to SWPPP, ESC30 and ESC31.

- Construct a durable working surface on prepared grades. Install a temporary hardened surface, commonly referred to as a "rat slab", atop the subgrade to protect it from disturbance by water and traffic. The rat slabs seal the subgrade from water and provide a durable surface to support foot and vehicle traffic and to lay out materials. At surface grades, rat slabs are typically constructed of asphalt pavement. In the deep excavation present on the NIF site, a lean concrete or controlled density fill $(C D F)^{1}$ is recommended which can be placed by pumping to the desired location. This material will sufficiently cure in less than a day, and it can be excavated to allow trenching for subsequent conduit installation. The surface preparation and rat slab placement in the excavation are shown in Photographs 12 through 17.

- Cover slopes to protect them from erosion damage. The fiber matting has already been installed on the perimeter slopes around the target bay, switchyards and diagnostics building areas. The interior slopes should be covered with plastic or shotcrete to prevent erosion from direct rainfall and from concentrated flows that may cascade from one pad down to another. Refer to SWPPP, ESC20. Photographs 18 and 19 show plastic cover installed in December.

1 The American Concrete Institute's terminology for this material is controlled low strength material, or CLSM. 


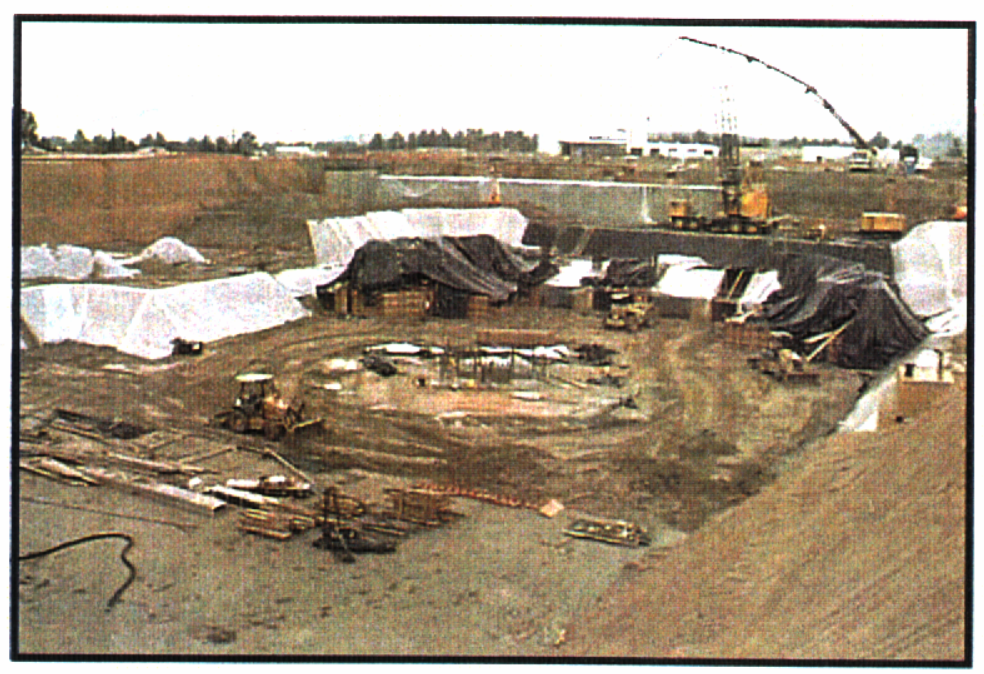

12. Removal of Disturbed Material in Preparation for Target Bay Rat Slab Placement.

13. Removal of Disturbed Material from Target Bay Subgrade.
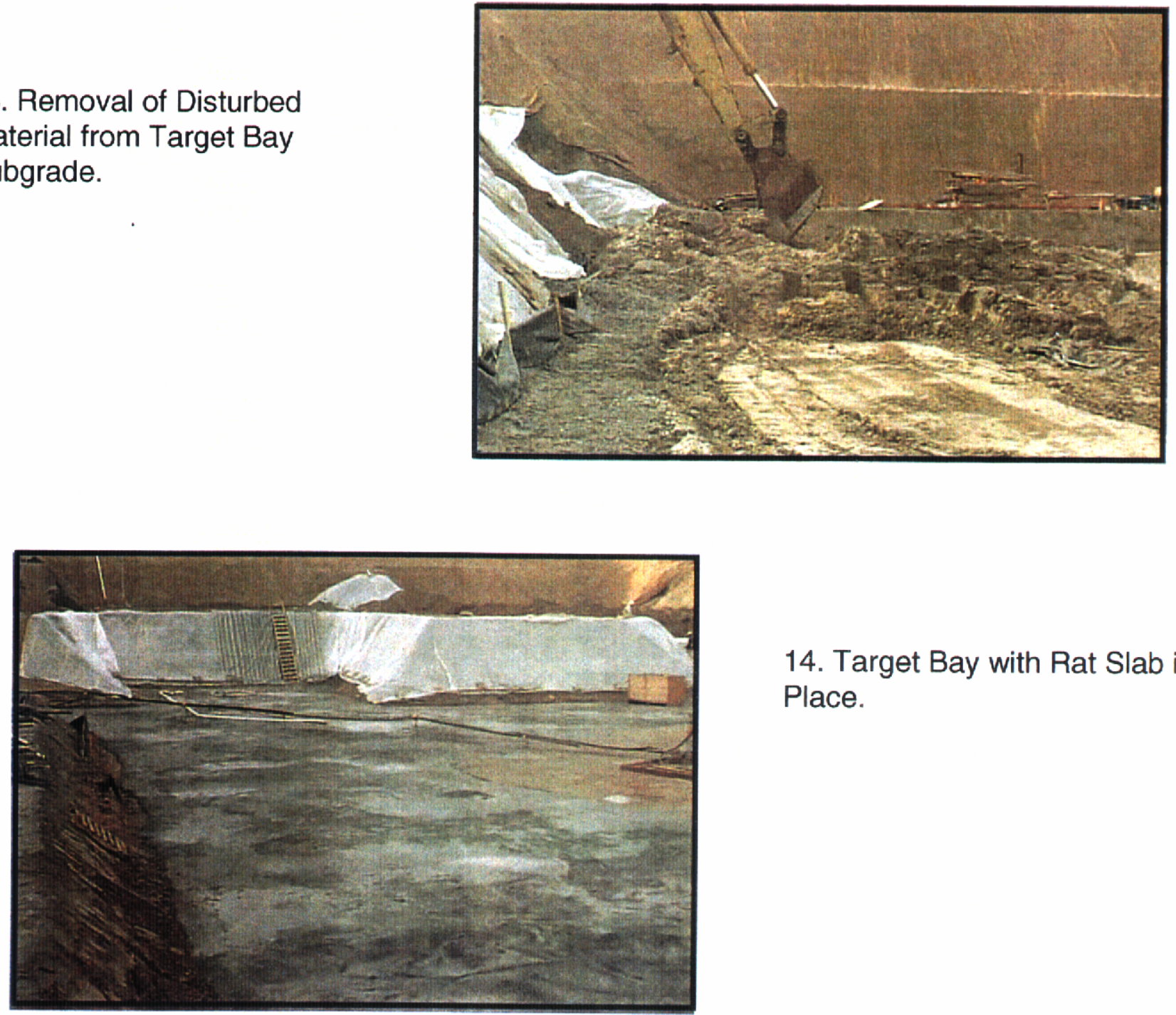

14. Target Bay with Rat Slab in Place. 


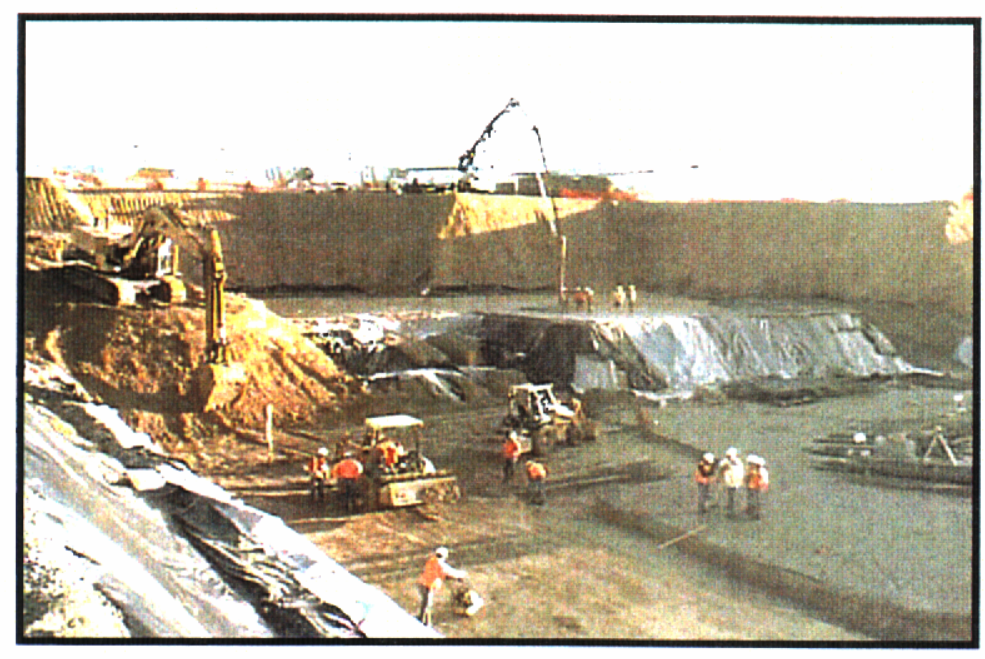

15. Pouring Rat Slab in South Switchyard.

16. South Switchyard Protected by Rat Slab and Contained with Sand Bag Dike.
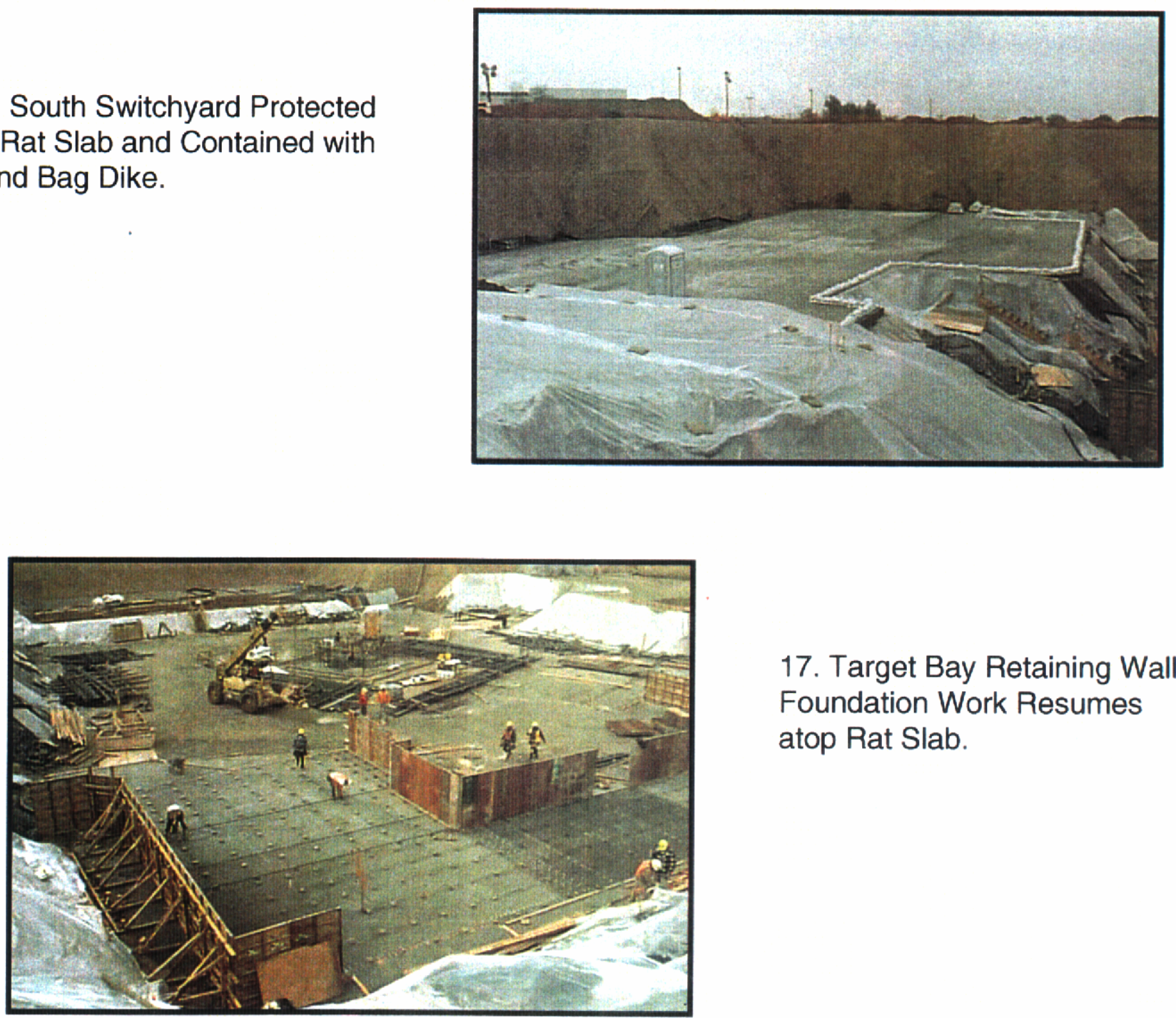

17. Target Bay Retaining Wall Foundation Work Resumes atop Rat Slab. 
- Contain runoff at the highest elevation possible in the excavation. Construct temporary earthen dikes to contain runoff on the foundation pads to prevent water from flowing to the bottom of the excavation where the current work is underway. Controlling water at the highest possible elevations accomplishes several objectives: (1) the flow path of the water is limited, thereby limiting the extent of potential erosion damage; (2) the height that water must be pumped to disposal sites is minimized; (3) the storage reduces the required pumping capacity by buffering peak flow rates; and (4) the amount of water that must be handled in and around the immediate work area is limited. The dikes should be constructed high enough to safely store the volume of water anticipated during extended winter storm events with an allowance for freeboard and scdiment storage, and they should be covered with plastic sheeting to control erosion and breaching. The dikes should also be set back from the top of slopes in accordance with the recommendations of the geotechnical engineer. Refer to SWPPP, ESC30 for earth dike construction; add plastic covering.

- Minimize duration of water storage in excavation. The time that water is stored in the excavation, particularly on unprotected subgrades, must be limited to avoid long-term saturation of the soils, minimize the potential for destabilizing the adjacent slopes and dikes, and to restore storage capacity for succeeding storm events. Pumping capacity should be sufficient to empty the excavation of ponded water within 24 hours of storm cessation and should not, therefore, be less than the anticipated 24-hour average inflow rate (refer to Photograph 20).

- Provide storage and treatment of runoff prior to disposal. Sufficient storage should be constructed outside of the excavation footprint to receive pumped discharges from the excavation. These storage facilities should also be sized to allow proper treatment of the runoff prior to discharge to catch basins and the storm sewer system.

- Protect disposal capacity. Catch basin inlets have been screened with filter fabric to trap sediments and control their discharge to the storm sewer system. The filter fabric surface area is limited to the inlet grate area, and this becomes blinded prematurely by runoff discharges that are heavily laden with suspended sediment. To protect the inlets from premature blinding, the effective surface area of filter fabric should be increased by constructing a filter fence around the inlet structure to function as a forebay and vertical filter face (refer to Appendix B, ESC 23). The further the fence is placed from the inlet, the longer the fence required and the greater filter surface area. The same effect can be created by placing a gravel berm (refer to Appendix B, ESC 26) and/or straw bales (Appendix B, ESC 24) around the inlet.

Recommended design criteria and suggested sizing of the above control methods are described in Section 4. 


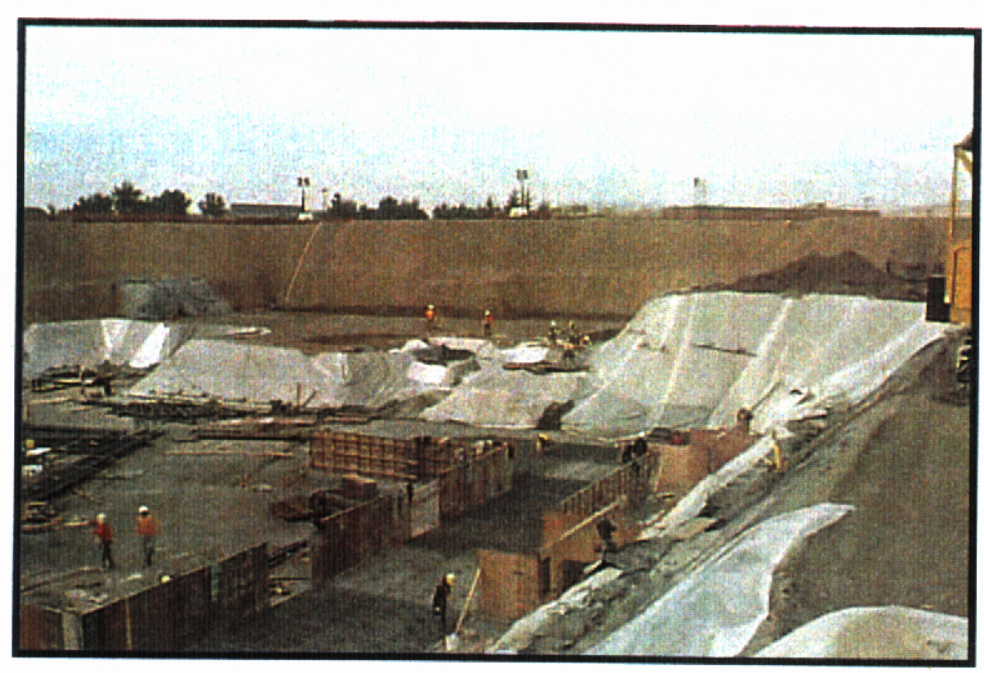

18. Plastic Sheeting Installed to Cover Excavation Slopes.

19. Protected Slopes and Subgrade in Target Bay.
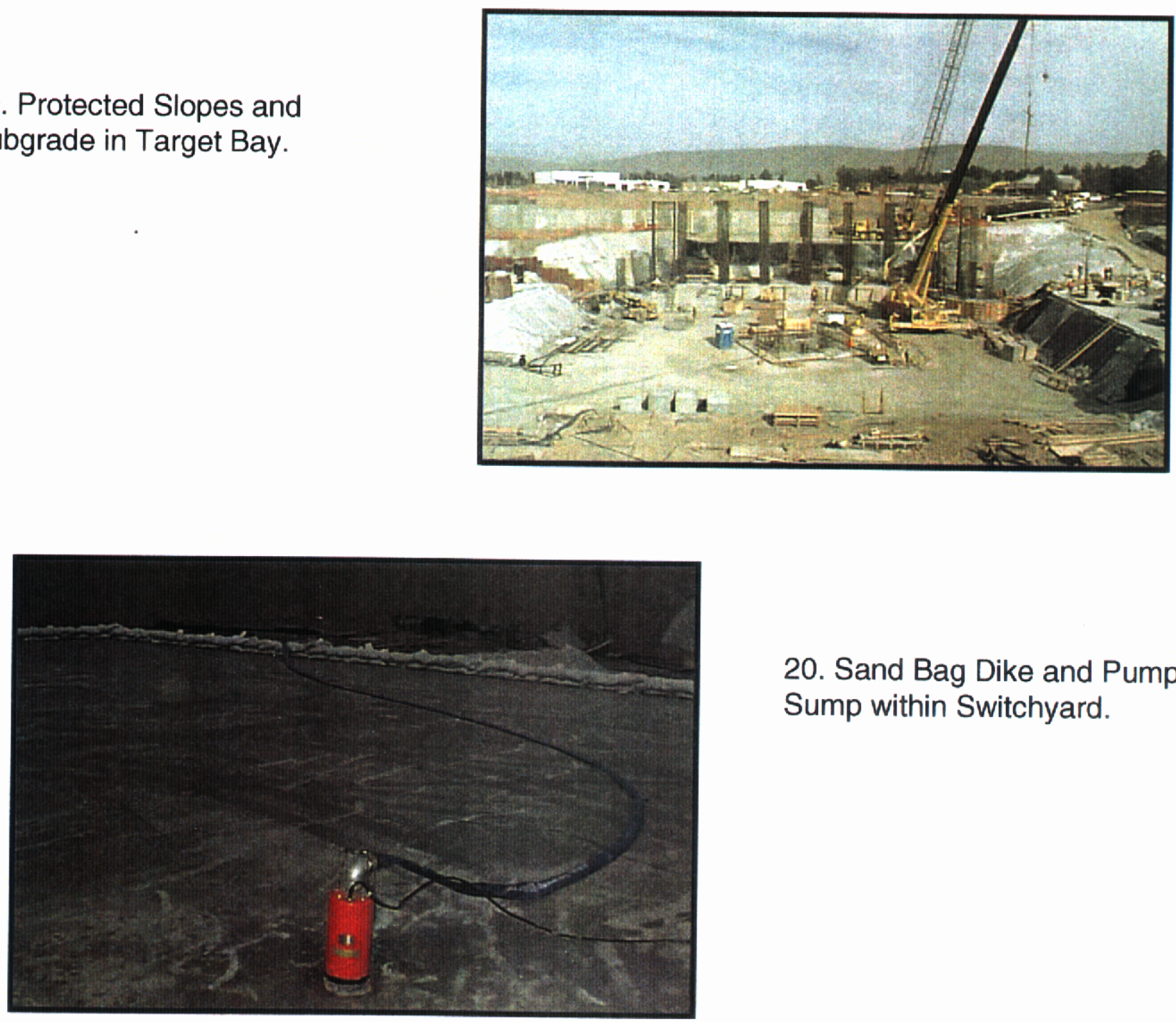

20. Sand Bag Dike and Pump in Sump within Switchyard. 


\section{ACCESS ROAD STABULIZATTON}

In addition to protecting excavation surfaces and slopes from water damage, construction roads to and within the excavation must be maintained in a stable condition to provide continuous allweather access to work areas for construction equipment and supplies. Maintaining a firm travel surface also helps to control the generation of mud that could flow into active work areas and hamper concrete placement and utility installation.

Methods of stabilizing construction roads were discussed and evaluated with on-site construction staff over the week of December 8 12. Alternatives considered included the following elements:

- Placement of crushed rock to provide a hardened traffic surface and distribute wheel loads over subgrade. This was the current practice and was recommended in conjunction with other stabilization techniques discussed below. It was recommended that a 12-inch layer of large rock (i.e., 3" to 8" diameter) be placed; however, stone of this size was not readily available, and therefore a 3-inch layer of $3 / 4$ " nominal size stone was used to surface the roads in conjunction with other techniques described below.

- Placement of geotextile fabric to distribute wheel loads and prevent migration of rock into subgrade. It was recommended that either this technique or soil additives be implemented with crushed rock surfacing to overcome low subgrade soil strength. The geotextile fabric, when placed between the subgrade and the rock surfacing, maintains the integrity and extends the useful life of the rock by preventing softer subgrade material from contaminating the gravel and reducing the strength of the rock matrix. The geotextile also distributes concentrated wheel loads over a greater surface area on the subgrade

- Application of a soil additive to control subgrade saturation and enhance soil strength. Mixing of a hydrating substance such as lime with the subgrade soils and recompacting is an effective means of drying and stabilizing soils with significant clay content (soils without sufficient clay content can be mixed with portland cement to form a soil-cement). This technique was recommended as an alternative subgrade treatment to geotextile fabric. This approach has the potential to leach lime into the runoff from the initial storm events following the application, and the collected runoff should be tested for $\mathrm{pH}$ prior to discharge from the site.

- Installation of subdrainage systems to control subgrade saturation and maintain soil strength. The conventional approach to stabilizing a roadbed is to maintain a welldrained subgrade. Perforated pipe trench drains could be installed along the access roads to carry away excess water. The pipes should be surrounded with crushed rock and the trenches should be lined with geotextile to prevent migration of finer soils into the rock. Prior to implementing this approach, the geotechnical engineer should be consulted as to the probability of successfully draining the fine grained soils 
present on the site. The pipe must also have sufficient wall strength and be protected from concentrated wheel loads to prevent collapse of the pipe.

The method implemented by construction personnel to stabilize the access roads was mixing a lime additive at a rate of 4 to 8 percent concentration with the subgrade soils to a depth of 12 to 18 inches and recompacting the mixture. This reinforced subgrade was then surfaced with a 3 inches course of $3 / 4$ " crushed rock. This stabilization method appeared to provide excellent service during site visit January 6 and 7, 1998. It is proposed by construction management personnel that runoff collected in the treatment basins outside the excavation will be tested prior to discharge from the site to determine if $\mathrm{pH}$ adjustment is required.

\section{EXISTING FOUNDATION PROTECTION}

Foundations constructed to support the capacitor bay structures abut the laser bays where storm runoff will collect prior to being pumped outside of the excavation. As other foundations are constructed in the course of the project, some will abut runoff collection points. It is important to safeguard the integrity of the soils underlying these foundations from potential saturation effects. Suggested methods to minimize degradation of foundation subgrade competency include (1) grading the runoff collection area to drain away from the foundation and (2) sealing the ground surface within the collection area to prevent percolation of runoff. Both methods have been implemented on the NIF site.

Earth Tech personnel did not perform tests of the on-site soils to predict the changes in their characteristics due to long-term saturation; however, the soils do not appear to be expansive and we would not expect the finer-grained soil particles to migrate from under the foundations when the soil drains assuming proper compaction prior to placing the concrete and assuming the soils are left undisturbed.

\section{OTHER CONSIDERED STRATEGILS}

The combined effect of the selected protection elements is to harden the ground surfaces of most of the construction site and to collect and pump stormwater from the site's center to its perimeter. Pouring rat slab throughout the lower levels of the excavation, lime treating the laser bays, covering slopes with plastic sheeting, and liming and rocking access roads and staging areas results in essentially impervious surfacing throughout the greater portion of the site. Alternatives that were considered in developing the strategy are described below:

- Paving the site with asphalt concrete pavement. A temporary asphalt concrete mat is constructed over the pad areas in the excavation and over traffic areas elsewhere on the site. The 3-inch thick asphalt mat is underlain with a 4-inch gravel base. Disadvantages of the approach, when compared to concrete rat slab, lime treatment, and lime/gravel access road construction are: (1) asphalt truck and heavy equipment access to the floor of the excavation, (2) disturbance to the prepared subgrade during roller compaction of the asphalt, and (3) difficulties with placing the asphalt in the short time windows between rainfall events. 
- Tenting areas of the excavation with fabric roof. A fabric roof is erected over a frame spanning the active work areas to prevent rain from interfering with concrete placement work. This could be considered a superior method from the standpoint of minimizing the presence of water in the work area method. Problems with implementing this approach are several, including: (1) with the exception of the $O A B$ excavation the work areas are too large to be spanned by available fabric roof frames, (2) long procurement times, (3) the need to construct structural supports for the frame, (4) maintaining safe clear distance between the crane and the fabric roof frame.

In comparison to the alternatives, the selected techniques of rat slab construction and lime treatment are cost-competitive with an asphalt pavement slab. The gravel/lime access road technique is cost-competitive with the heavier asphalt pavement section required to support equipment traffic. The selected methods are readily implemented, and could be constructed within the limited clear-weather windows, or in some cases, during inclement weather.

Estimated units costs for procuring and implementing these alternative approaches were developed with input from on-site construction management personnel and are presented Table 1. The costs of implementing the recommended remedial and protective measures on the site are discussed in Section 5.

Table 1. Estimated Unit Costs for Alternative Surfacings

\begin{tabular}{|l|c|}
\hline \multicolumn{1}{|c|}{ Protection Method } & Estimated Unit Cost ${ }^{*}$ \\
\hline Concrete rat slab & $\$ 1.00 / \mathrm{sf}$ \\
\hline Lime treatment & $\$ 1.09 / \mathrm{sf}$ \\
\hline Asphalt concrete pavement (slab) & $\$ 0.98 / \mathrm{sf}$ \\
\hline Gravel/lime access roadway & $\$ 1.40 / \mathrm{sf}$ \\
\hline Asphalt concrete pavement (access road) & $\$ 1.55 / \mathrm{sf}$ \\
\hline Fabric roof & $\mathrm{N} / \mathrm{A}$ \\
\hline
\end{tabular}

* Cost does not include subgrade remediation and preparation. 


\section{Section 4: Design Criteria and Sizing of Controls}

This section presents performance criteria selected for use in design of the temporary runoff control methods on the NIF construction site. These criteria were then applied to the site to size storage and conveyance elements of the wet weather protection strategy.

\section{PRECIPITATION}

Precipitation patterns were selected to serve as a design basis for runoff controls in and around the excavation. These patterns, or design storm events, are defined both in terms of total precipitation depth and peak intensity. The total precipitation depth is important to determining the necessary storage volume to capture anticipated storm events, whereas the peak intensity is the key parameter to sizing conveyance capacity of pumps and other conveyance facilities.

Design storm events with an average return frequency of 1 to 2 years are typically used for design of temporary stormwater controls such as those employed during construction. However, because of the potential consequences of a storm-caused delay of critical construction activities, a more rigorous performance standard can be argued. Another consideration in selecting a more rigorous design storm return frequency was the outlook for extremely wet weather over the winter of 1997-8. The El Niño climate pattern presents a probability of greater than average rainfall over the 1997-98 winter. Considering that the historical frequency of El Niño weather patterns is roughly 10 years (personal communication, Jim Ellis, LLNL Meterologist), a 10-year design storm return frequency was selected as the design basis for the temporary control facilities, assuming $E \mathrm{I}$ Niño effects are represented in published historical precipitation statistics.

Another parameter of the design storm is the duration of the event. Typically shorter duration events have greater rainfall intensities and correspondingly higher peak rates of runoff, whereas longer duration events produce greater overall precipitation depth and, hence, runoff volumes. Table 1 presents summaries of total precipitation depths for consecutive days of rainfall recorded at Berkeley, California, and the corresponding average rainfall intensities. Statistical information available for Mt. Diablo Junction, which is higher in elevation than Livermore, was very similar to that of Berkeley; hence, the Berkeley data was considered appropriate to the Livermore region.

The statistical information in Table 1 was compared to isopluvial maps obtained from the Natural Resources Conservation Service (formerly Soil Conservation Service) in Davis, California. Information derived from these maps for Berkeley and Livermore is summarized in Table 2. 


\begin{tabular}{|c|c|c|}
\hline $\begin{array}{c}\text { Consecutive Days } \\
\text { of Rainfall }\end{array}$ & $\begin{array}{c}\text { Total Precipitation Depth } \\
\text { (inches) }\end{array}$ & $\begin{array}{c}\text { Average Rainfall Inteasity } \\
\text { (inches per day) }\end{array}$ \\
\hline 1 & 4.02 & 4.02 \\
\hline 2 & 5.06 & 2.53 \\
\hline 3 & 5.70 & 1.90 \\
\hline 4 & 6.25 & 1.56 \\
\hline 5 & 6.77 & 1.35 \\
\hline 6 & 7.27 & 1.21 \\
\hline 8 & 8.18 & 1.02 \\
\hline 10 & 8.78 & 0.88 \\
\hline
\end{tabular}

from California Department of Water Resources

Table 3. 10-Year Storm Precipitation Depths, Berkeley and Livermore, CA.

\begin{tabular}{|c|c|c|}
\hline Storm Duration & Berkeley & Livermore \\
\hline 6 hours & 2.2 & 1.8 \\
\hline 24 hours & 4.0 & 3.5 \\
\hline
\end{tabular}

from Natural Resources Conservation Service

The only comparative data point between Tables 1 and 2 is the one-day (24-hour) precipitation depth in Berkeley, and these values are consistent with one another. The information in Table 2 indicates that precipitation depths in Livermore are slightly less, for a given return period, than in Berkeley. The Berkeley statistics for total precipitation depths were used for the NIF site in Livermore, introducing a conservative factor to the resultant designs.

The stormwater controls to be employed on the site that are subject to the precipitation design criteria are (1) storage behind dikes on the foundation pads and (2) pumping from these pads to (3) storage outside the excavation prior to treatment and disposal. The more intense rainfall of the one-day duration storm pattern ( 4.0 inches in 24 hours) was selected for sixing pumping and other conveyance facilities such as storm drains. The one-day storm pattern is also consistent with the objective of removing collected runoff from the excavation within 24 hours. The greater overall precipitation depth from the five-day duration storm pattern (6.77 inches in 5 days) was selected for establishing storage facility capacities. Five-day storm durations are considered characteristic of El Nino cycles. The five-day criteria provides a contingency for storing runoff from extended storms, for storing runoff from storm events greater than the 10year frequency event, and for storing runoff in the event of a pumping failure. 
An cstimate of peak rainfall intensity was desired to evaluate instantaneous runoff inflow rates to critical work areas such as the retaining wall footing currently under construction. Local storm duration/intensity factors (City of Livermore) were applied to develop estimates of instantaneous peak rainfall intensities. A review of these estimates showed they were consistent with the overall storm depth estimates in Table 1. Published precipitation distribution patterns (hyetographs) for local rainfall events were not available. The local storm duration/intensity factors were therefore used to produce the synthesized design storm hyetograph shown in Figure 3 for a 10-year return frequency, 24-hour duration storm event. The hyetograph segregates the 24-hour precipitation depth into 10-minute segments. Actual storm precipitation distributions will vary from the synthetized hyetograph; however, the peaking factors from the City of Livermore are concluded to be representative of local conditions and should be satisfactory if applied with appropriate factors of safety.

The synthesized design storm hyetograph was translated into runoff hydrographs using the Santa Barbara Urban Hydrograph methodology. The ground surface was characterized in the modeling as an impervious surface similar to pavement because the clay content in the exposed soils effectively seal the ground surface and because protected areas in the excavation will be covered with rat slabs, plastic sheeting or other impervious surfacing. The results of the modeling produced an estimated peak rate of runoff of 0.79 cubic feet per second or 350 gallons per minute (gpm) from one acre of impervious ground.

\section{STORAGE}

The wet weather protection strategy employs dikes to create storage on each foundation pad within the excavation. For each storage location, the tributary drainage area and available storage area were estimated from the NIF excavation design drawings. Applying the 10-year frequency, 5-day duration precipitation depth of 6.77 inches to the tributary drainage areas, the total runoff was computed and the resulting depth of storage was determined. The depth of storage plus an allowance for freeboard, sediment storage and irregularities in dike construction was used to establish recommended dike heights. Table 3 presents the recommended dike heights for each storage area. 
Table 4. Recommended Dike Heights and Pump Capacities.

\begin{tabular}{|l|c|c|c|}
\hline $\begin{array}{c}\text { Storage } \\
\text { Location }\end{array}$ & $\begin{array}{c}\text { Storage } \\
\text { Elevation } \\
\text { (feet) }\end{array}$ & $\begin{array}{c}\text { Recommended } \\
\text { Dike Height } \\
\text { (feet) }\end{array}$ & $\begin{array}{c}\text { Recommended } \\
\text { Pump Capacity } \\
\text { (gpm) }\end{array}$ \\
\hline South Laser Bay & 611.50 & 2.6 & 100 \\
\hline North Laser Bay & 611.50 & 2.5 & 100 \\
\hline Tunnel & 594.00 & 2.6 & 75 \\
\hline Target Bay & 574.00 & 2.7 & 90 \\
\hline North Switchyard & 586.75 & 2.7 & 40 \\
\hline South Switchyard & 586.75 & 2.7 & 40 \\
\hline Diagnostics & 579.25 & 2.7 & 40 \\
\hline Optics Assembly Bldg. & 608.83 & 2.2 & 50 \\
\hline Optics Assembly Bldg. & 592.50 & N/A & 20 \\
\hline
\end{tabular}




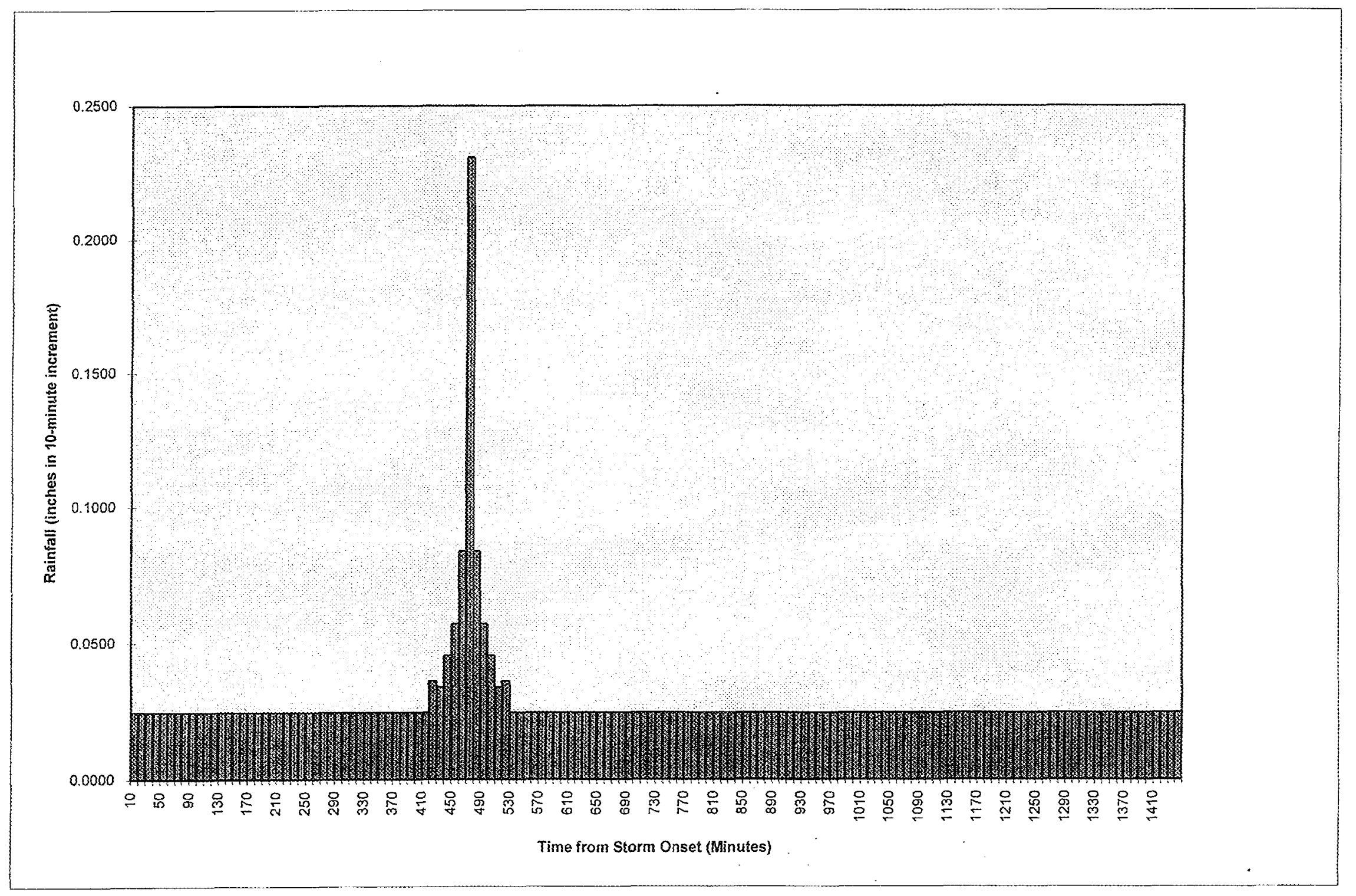

Figure 3 - Synthezised 10-year Design Storm Hyetograph LLNL - National Ignition Facility Wet Weather Construction Plan 


\section{PUMPING}

Pumping will be used to convey runoff collected and stored behind the dikes to treatment and disposal facilities outside of the excavation. For each storage location, the volume of runoff to be collected from a 10-year frequency, one-day duration storm event (precipitation depth of 4.0 inches) was computed. Recommended pumping capacity was determined as that required to evacuate the computed storage volume within 24 hours. The recommended pump capacity for each storage area is shown in Table 3.

In the work area of the retaining wall footing under construction at the time of the site reconnaissance, it was critical that water not be allowed to pond in the work area. In this location a pumping rate equal to the instantaneous peak runoff rate to the immediate work area is recommended. The recommended pumping capacity is 200 gallons per minute (gpm).

\section{DISCHARGE}

There are several locations where drainage from the construction site discharges to the local storm drainage system. Discharge to area storm drains is through catch basin inlets to collector storm drains that in turn discharge to trunk lines. Figure 4 is a plan showing the location of the various storage and pumping facilities recommended in the wet weather protection strategy. Figure 5 is a schematic representation of the various storage areas within the excavation. The recommended dike height and pumping capacity for each storage area is listed on Figure 5, and the directions in which the stored flows are to be pumped are indicated by arrows. Where one storage area is pumped to another for subsequent pumping out of the excavation (e.g., target bay flows are pumped to the north switchyard and then pumped to the north treatment basin), the combined pumping requirement is shown next to the arrow. Where alternative pumping destinations are available they are shown by multiple arrows denoted ' $A$ ' and ' $B$ '.

The inlet and barrel capacities of each catch basin available to receive flows from the site were assessed and are shown on Figure 5. These inlet capacities have not been reduced to account for blinding by accumulated sediment. The estimated storage volume is listed for each storage area identified outside of the excavation. For each storage area, the volume listed represents an estimate of the existing available storage as of December 5, with the exception of the east treatment basin. It is proposed that the east treatment basin be constructed by excavating between Catch Basins 1 and 2 to create a shared storage facility which can discharge through either catch basin. 


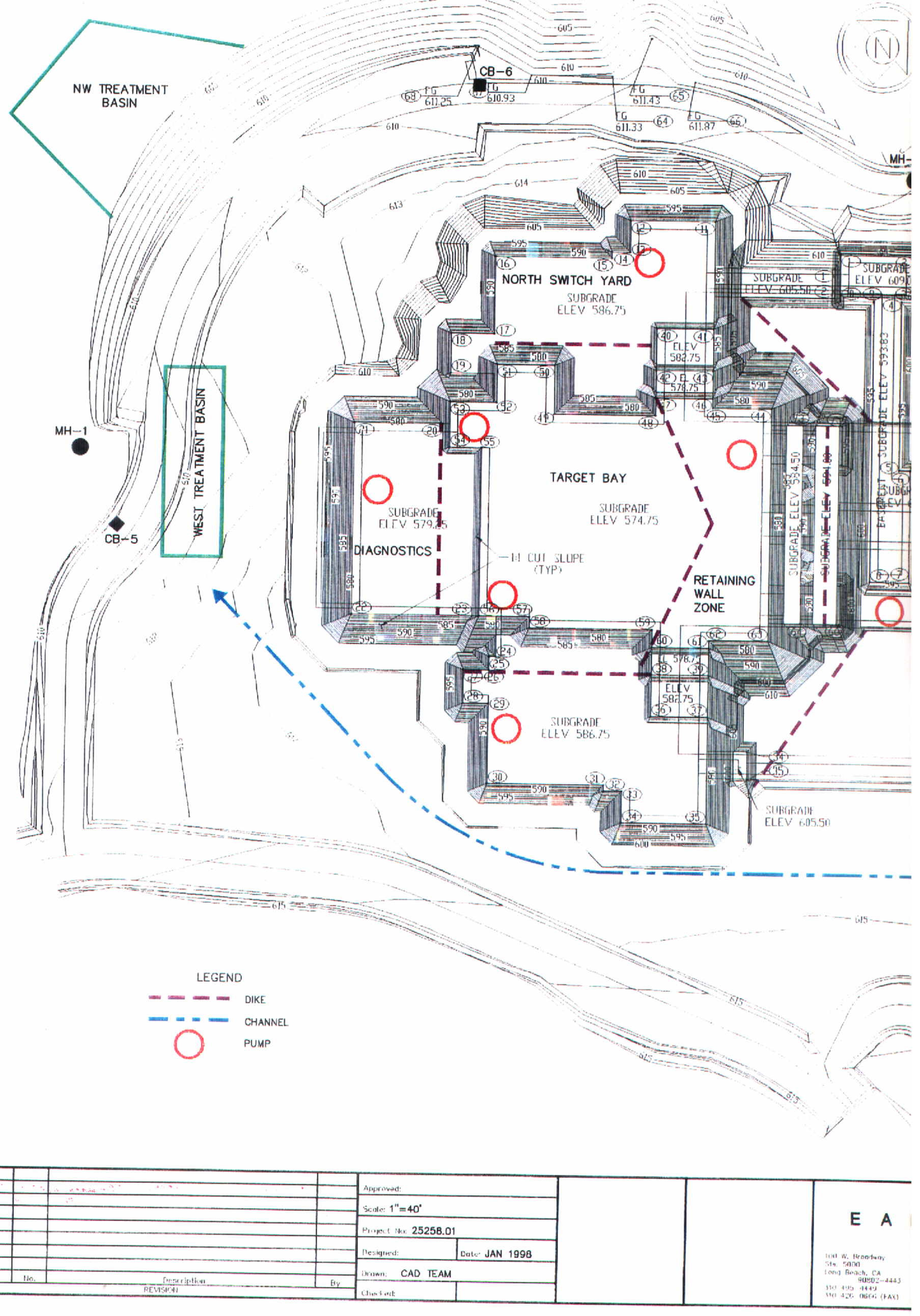




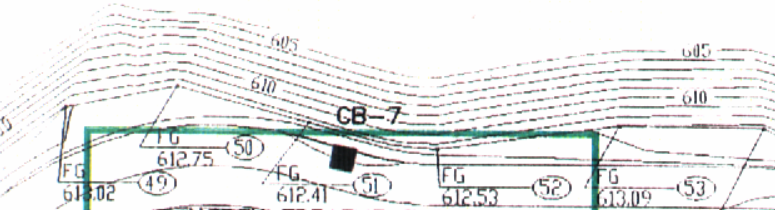
NORIEE FREATMENT BASIN

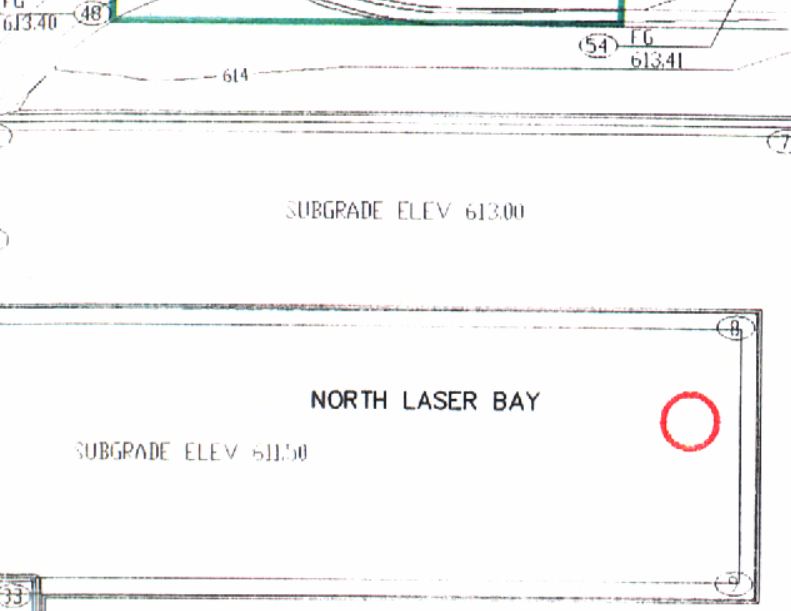

SOUTH LASER BAY

WUBCRADF FIFV 611.50

SUBGRADE LLLIV $6,13,00$

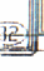

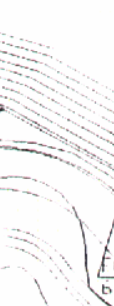

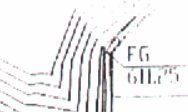

$(57)$
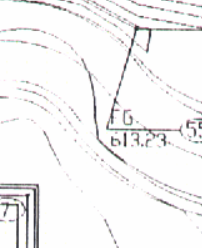

$5 G \quad 50$

(6ii)

- (63)

NE TREATMENT BASIN
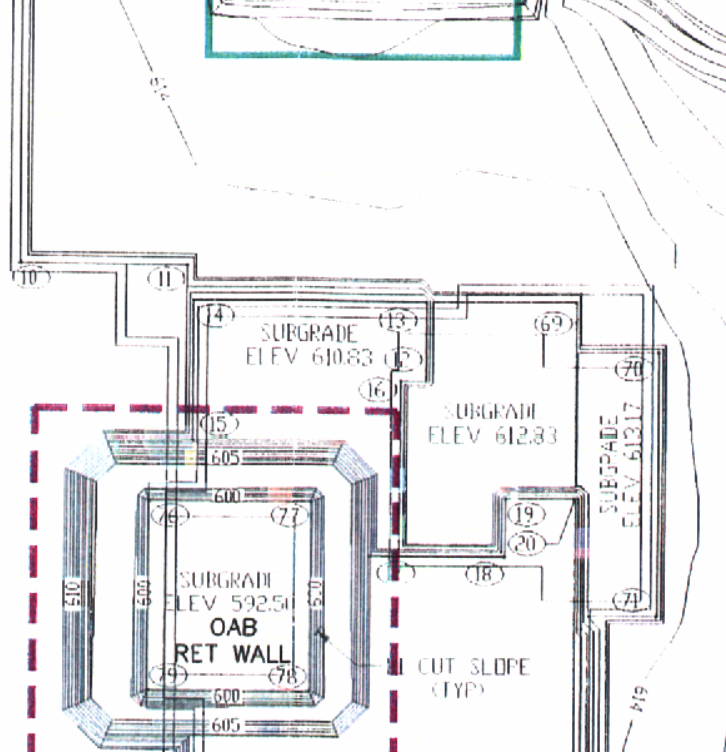

L $--11-\ldots$
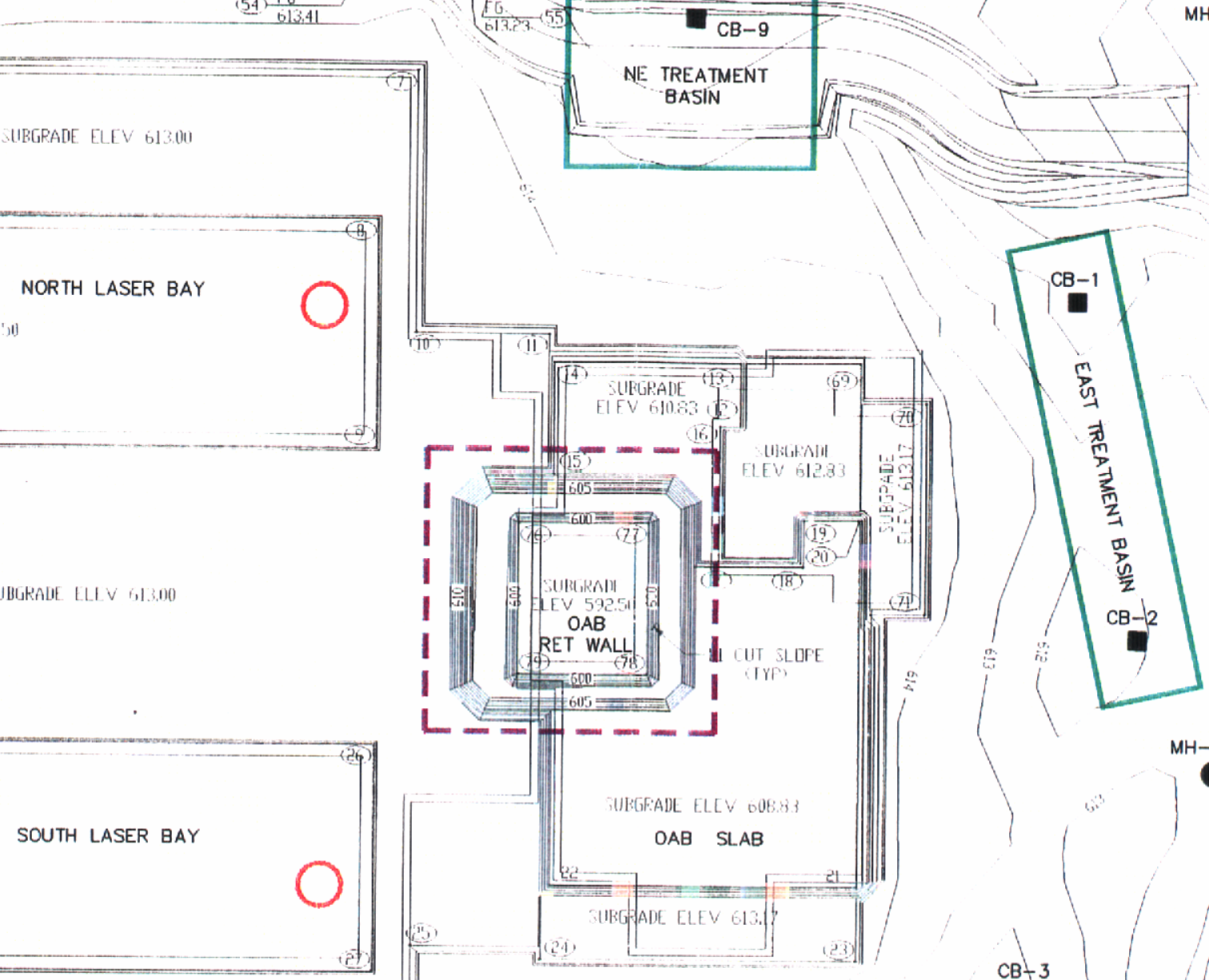

SUBGRADE ELEV M.T.00
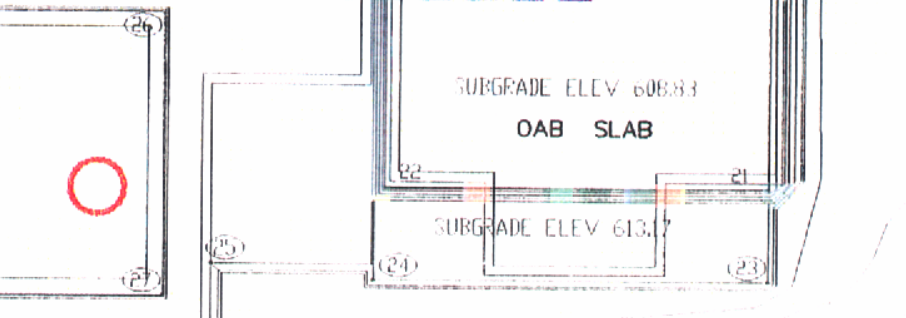

1

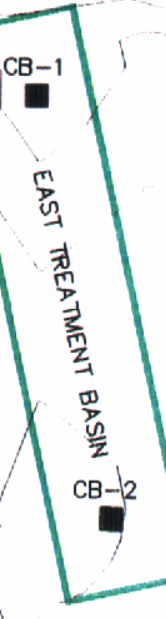

CB-13
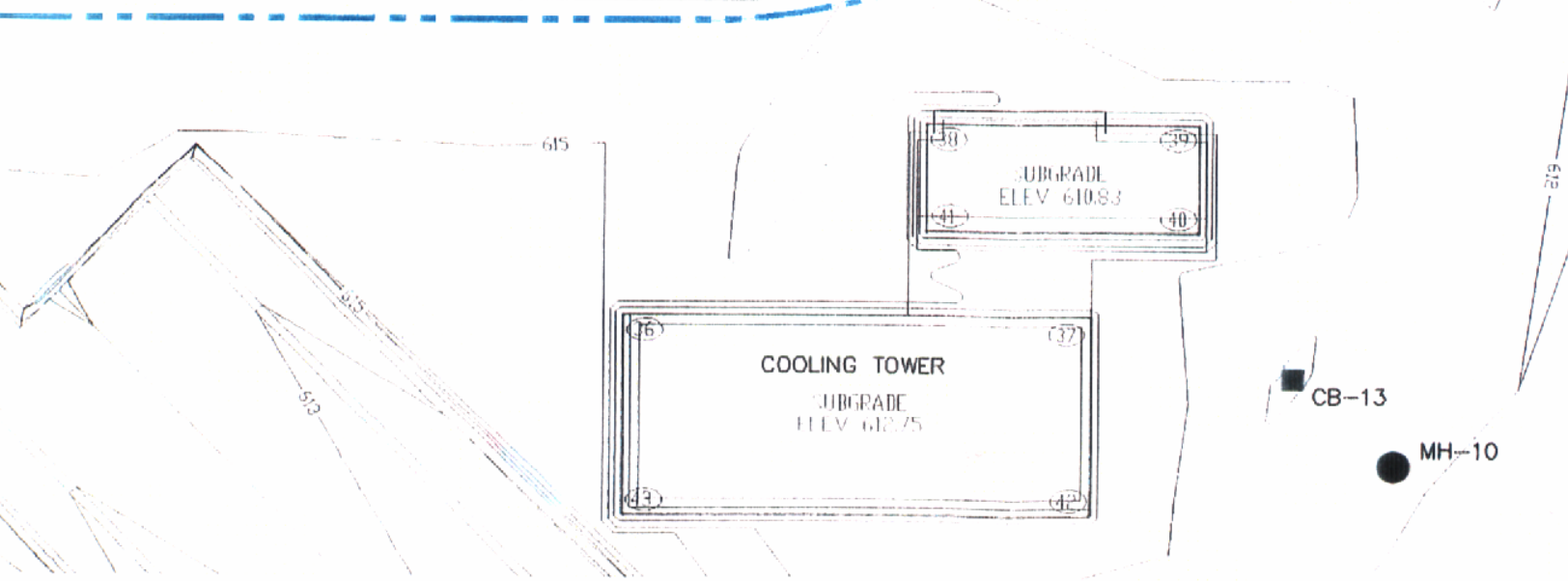

MH-10
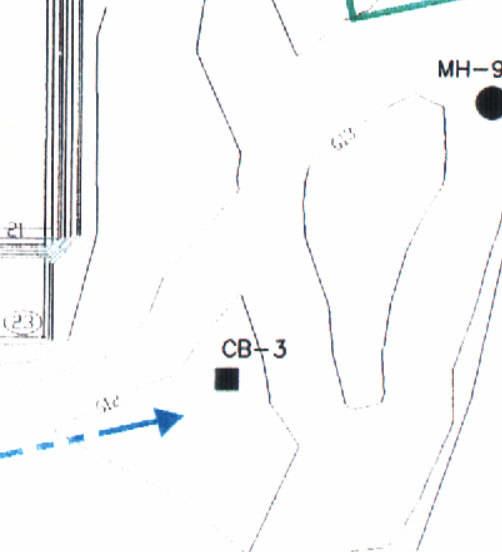

\section{LAWRENCE LIVERMORE NATIONAL LABORATORY}

FIGURE 4

WET WEATHER CONSTRUCTION PLAN LOCATION OF STORAGE AND PUMPING FACILITIES
Drameig InFr:

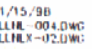
DRAWIHC: HO) 1 


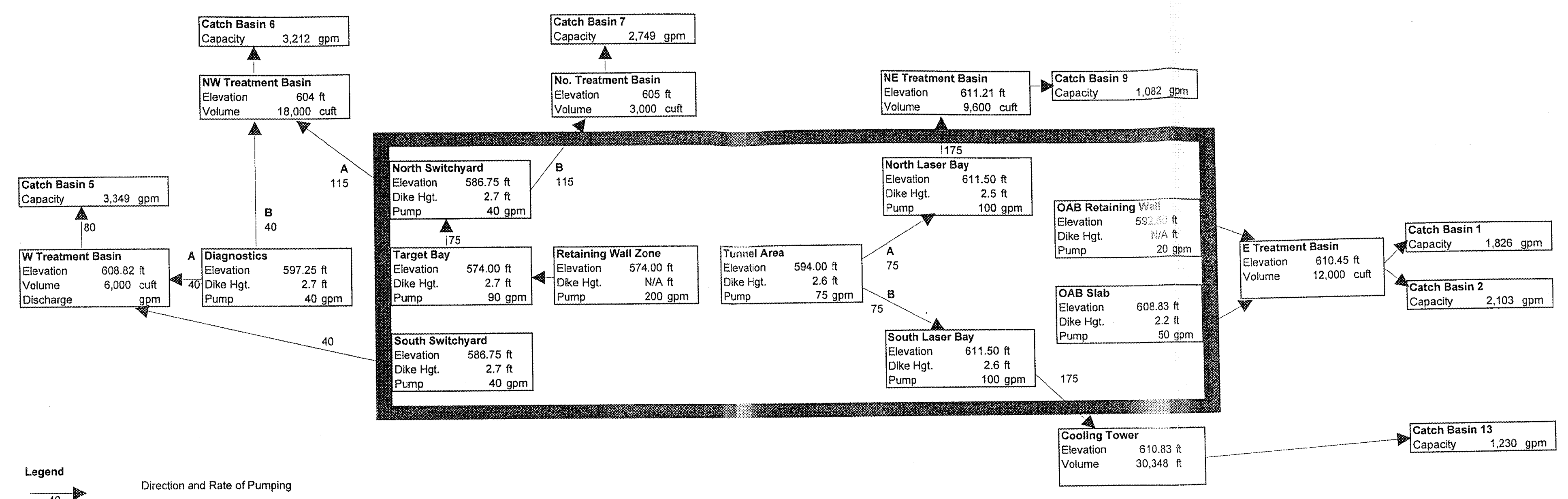

Figure 5 - Storage and Pumping Configuration LLNL - National Ignition Facility Wet Weather Construetion Plan 


\section{Section 5: Estimated Implementation Costs}

As of early January 1998, the cost to remediate the site for damage caused by prior rainfall events and the implement wet weather protective measures is estimated to total $\$ 644,000$. A breakdown of this estimate is presented in Table 5.

\section{Table 5. Implementation Costs}

\begin{tabular}{|c|c|}
\hline 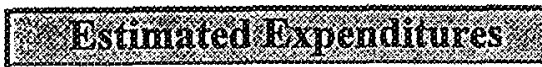 & Wortseriformed \\
\hline$\$ 44,000$ & $\begin{array}{l}\text { Excavate mud and prepare subgrade in Target Bay } \\
\text { retaining wall work area. } \\
\text { Place concrete rat slab in Target retaining wall work } \\
\text { area. }\end{array}$ \\
\hline$\$ 275,000$ & $\begin{array}{l}\text { Excavate mud and prepare subgrade in remainder of } \\
\text { Target Bay } \\
\text { Regrade North and South Switchyards and fill utility } \\
\text { trenches } \\
\text { Place concrete rat slab in remainder of Target Bay and } \\
\text { in No. \& So. Switchyards }\end{array}$ \\
\hline$\$ 75,000$ & $\begin{array}{l}\text { Install plastic sheeting on excavation slopes } \\
\text { Pump procurement and operation } \\
\text { Excavate mud and prepare subgrade in } O A B \text { retaining } \\
\text { wall work area }\end{array}$ \\
\hline$\$ 250,000$ & $\begin{array}{l}\text { Lime treat subgrade in North and South Laser Bays } \\
\text { Lime treat and gravel access roads and staging area }\end{array}$ \\
\hline
\end{tabular}

Throughout the wet weather season, costs are expected to be incurred for operating and maintaining pumps and dikes, modifying measures to accommodate shifting work locations, and monitoring the performance and quality of discharges to the storm drainage system. 


\section{Section 6: Monitoring and Adjustments}

As construction proceeds, the location and elevation of the work will shift within the excavation footprint. The information provided for each work area shown in Figure 5 can be used to reconfigure the control strategy, redirect flows and make other adjustments as they become necessary. Based on a review of the construction schedule with construction management personnel, the following discussion is presented of specific drainage aspects that should be monitored and adjusted as construction progresses.

- Storage sumps and discharge basins (at catch basins) should be monitored for sediment accumulation, and sediment should be removed regularly to preserve storage volume for succeeding storm events. Water should not be stored on prepared subgrades longer than 24 hours following storm cessation so as to minimize saturation.

- Integrity of the constructed temporary dikes should be inspected by the geotechnical engineer.

- Backfilling in the southeast comer of the site will not be complete in time to allow installation of the permanent drainage system in that area by its scheduled October 1998 completion date. A temporary means of conveying runoff from this area must be developed prior to the 1998-99 wet weather season.

- As the walls are constructed in the switchyard and diagnostics building areas, we understand the floor slabs will be constructed concurrently and backfill placed around the outboard side. This plan of construction will create a basin outside of the walls that will trap water. Runoff collection and pumping capabilities should be maintained in service and modified as needed to protect the integrity of the backfill. Rain falling inside the walls of the structure will flow to the lowest floor level through floor slab penetrations. This water should be relatively clean (absent contact with solvents, curing compounds or other construction materials) and can be pumped out of the structure to a direct discharge without treatment.

- The laser bays will be framed and roofed prior to the 1998-99 wet weather season. This will protect work areas within the laser bay, however the permanent storm drainage system should be ready to receive runoff from the new roof areas so that the clean runoff can be discharged directly without treatment.

- Update wet weather control strategies as grading within the excavation changes, and amend the SWPPP, as appropriate, with the information provided in this report. 
- It is strongly recommended that, by late summer 1998, the wet weather protection plan be comprehensively reviewed and updated to address the construction activities scheduled and conditions anticipated through the 1998-1999 wet weather season. 


\section{Appendix $\mathbf{A}$}

\section{Bibliography}


Climate Outlook, National Center for Environmental Prediction, November 1997.

Construction Drawings, CSP-2 for Site Excavation at Livermore Site National Ignition Facility, 24 March 1997, Parsons Infrastructure and Technology Group, Inc.

ENSO Extreme Event Risk, Climate Diagnostics Center, National Oceanic and Atmospheric Center, November 1997.

Facilities Planning Guidelines, City of Livermore, August 1995.

King County, Washington, Surface Water Design Manual, revised November 1994.

Precipitation data for selected California locations, National Weather Service.

Precipitation-Frequency Atlas of the Western United States, NOAA Atlas 2, California, Soil Conservation Service.

Rainfall Return Periods, San Francisco Bay Area, updated data set, Goodridge, J.D., California Department of Water Resources, 1997.

Specification OCS -0068, CSP-2 for Site Excavation at Livermore Site National Ignition Facility, 24 March 1997, Parsons Infrastructure and Technology Group, Inc., Volume No. 2 of 3.

Specification OCS-0071, CSP-3 Target Building Mat \& Laser Bay Foundations at Livermore Site National Ignition Facility, 28 May 1997, Parsons Infrastructure and Technology Group, Inc., Volume No. 2 of 2. 


\section{Appendix $\mathbf{B}$}

Excerpts from:

Stormwater Best Management Practices Guidebook

Boise City

Public Works Department

Draft - October 24, 1996 


\section{BMP: Silt Fence Rे Aff}

\section{OBSECTIVES: \\ .}

\section{GENERAL DESCRIPTION}

A silt fence is made of a filter fabric which has been entrenched, attached to supporting poles, and sometimes backed by a wire fence for support. The silt fence detains sediment-laden water, promoting sedimentation behind the fence.

\section{SUITABLE APPLICATIONS}

- Along the perimeter of the site and around temporary spoil areas.

- Below the toe of a cleared slope or other small cleared areas.

- Along streams and channels.

- Across swales with catchments less than 1 acre.

\section{LIMITATIONS}

- Cannot use in streams, channels, or anywhere there is concentrated flow.

- Cannot use where drainage areas are more than 1 acre in size and flow rates exceed $0.5 \mathrm{cfs}$.

\section{INSTALLATION/APPIICATION GUIDELINES}

- Install along a level contour, so water does not pond more than $1.5^{\prime}$ at any point.

- Limit concentrated flow to less than $1 \mathrm{acre}, 100^{\prime}$, or $0.5 \mathrm{cfs}$ at any point along the silt fence.

- Provide area behind the fence for runoff to pond and sediment to settle (approx. 1200 sq. ft. per acre draining to the silt fence).

- Avoid using where $85 \%$ of the soil, by weight, passes through a No. 200 sieve because the filter fabric will clog.

\section{MAINTENANCE REQUIREMENTS}

- Inspect weekly and after each rainfall. Repair wherever fence is damaged.

- Remove sediment when it reaches $1 / 3$ the height of the fence.

\section{COST CONSIDERATIONS}

Relatively inexpensive.

\section{DESIGN LIFE}

6 months

\section{POLIUTANT REMOVAL RFFECTIVENESS}

Floatable materials

() Nutrients

Toxic chemicals
Sediment

Oil and grease

O Other construction waste
MPLEKKNTATION REQURREENTS

Capital Costs

O\&M Costs

Maintenance

Training 


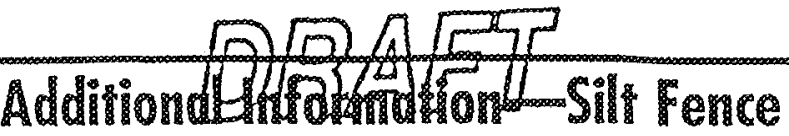

\section{ENERAL INFORMATION}

A silt fence is a temporary sediment barrier consisting of filter fabric stretched across and attached to supporting posts, entrenched, and, depending upon the strength of the fabric used, supported with wire fence. Silt fences trap sediment in two ways: (1) by intercepting and detaining small amounts of sediment from disturbed areas during construction operations in order to promote sedimentation behind the fence; and (2) by decreasing the velocity of low flows (up to $0.5 \mathrm{cfs}$ ) in swales.

Silt fences may be used for perimeter control, placed upstream of the point(s) of discharge of sheet flow from a site. They may also be used as interior controls below disturbed areas where runoff may occur in the form of sheet and rill erosion, and perpendicular to minor swales or ditch lines for up to one acre contributing drainage areas. Silt fences are generally ineffective in locations where the flow is concentrated and are only applicable for sheet or overland flows. stallation/Application

Planning:

Silt fences are generally most effective when the following placement criteria are followed:

- Limit the upstream drainage area to 1 acre or less when used alone or in combination with sediment basin in a larger site.

- The maximum slope perpendicular to the fence line should be 1:1.

- Limit the maximum sheet or overland flow path length to any point along the fence to $100^{\prime \prime}$.

- Limit the concentrated flows reaching the fence to $0.5 \mathrm{cfs}$.

Silt fences are preferable to straw barriers in many cases. While the failure rate of silt fences is lower than that of straw barriers, there are many instances where silt fences have been improperly installed. The following installation methods can improve silt fence performance:

- Construct the silt fence along a level contour.

- Silt fences should remain in place until the disturbed area is permanently stabilized.

- Provide sufficient room for runoff to pond behind the fence and to allow sediment removal equipment to pass between the silt fence and toes of slopes or other obstructions. About 1200 sq. ft. of ponding area should be provided for every acre draining to the fence.

- Turn the ends of the filter fence uphill to prevent storm water from flowing around the fence.

- Leave an undisturbed or stabilized area immediately downslope from the fence.

- Do not place in live streams or intermittently flowing channels.

Design:

Selection of a filter fabric is based on soil conditions at the construction site [which affect the equivalent opening size (EOS) fabric specification] and characteristics of the support fence (which affect the choice of tensile strength). The designer should specify a filter fabric that retains the soil found on the construction site yet will have openings large enough to permit drainage and prevent clogging. Below is a list of guidelines for selecting the EOS:

- If 50 percent or less of the soil, by weight, will pass the U.S. standard sieve No. 200 , then select the EOS to retain 85 percent of the soil. The EOS should not be finer than EOS 70 . 


\section{Addifional Information-Silt Fence}

- For all other soil types, the EOS should be no larger than the openings in the U.S. Standard Sieve No. 70 [0.0083 in. $(0.21 \mathrm{~mm})$.$] except where direct discharge to a stream, lake, or wetland will occur, then$ the EOS should be no larger than Standard Sieve No. 100.

To reduce the chance of clogging, it is preferable to specify a fabric with openings as large as those specified above. No fabric should be specified with an EOS smaller than U.S. Standard Sieve No. 100 [0.0059 in. $(0.15 \mathrm{~mm}$.)]. If 85 percent or more of a soil, by weight, passes through the openings in a No. 200 sieve [0.0029 in. (0.074 mm.)], filter fabric should not be used. Most of the particles in such a soil would not be retained if the EOS was too large, and they would clog the fabric quickly if the EOS was small enough to capture the soil.

Support the fence with wire mesh if the fabric selected does not have sufficient strength and bursting strength characteristics for the planned application (as recommended by the fabric manufacturer). Filter fabric material should contain ultraviolet ray inhibitors and stabilizers to provide a minimum of six months of expected usable construction life at a temperature range of $0^{\circ} \mathrm{F}$ to $120^{\circ} \mathrm{F}$.

Installation Guidelines:

Construct filter fences on a level contour. Provide sufficient area behind the fence for water to accumulate. If the area behind the fence is not large enough to hold water, then the fence may collapse causing flooding to occur. The following guidelines should be observed when installing a silt fence:

- Space posts ar least of $6^{\prime}$ apart and drive securely at least $30^{\prime \prime}$ into the ground.

- Excavate a trench approximately 8 " wide and $12^{\prime \prime}$ deep along the line of posts and upslope from the barrier.

- When using standard strength filter fabric, securely fasten a wire mesh support fence to the upslope side of the posts using 1 "(or longer) heavy-duty wire staples, tie wires or hog rings. Extend the wire into the trench to a depth of at least $4^{\prime \prime}$.

- Staple or wire standard strength filter fabric to the fence, and extend $40^{\prime \prime}$ of the fabric into the trench. When using extra-strength filter fabric and posts that are spaced closer together, you can eliminate the wire mesh support fence and staple or wire the filter fabric directly to the posts.

- Avoid using joints. Purchase the filter fabric in a continuous roll, then cut to the length of the barrier. If using joints is unavoidable, then splice filter cloth together at a support post, overlapping the cloth at least a 6 ". Securely fasten both ends to the post.

- Backfill the trench with compacted soil.

\section{infenance Requirements}

- Inspect monthly during dry periods and immediately after each rainfall. Repair as necessary.

- Remove sediment when it reaches approximately one third the height of the fence.

- Do not remove silt fences until the upslope area has been permanently stabilized.

- Do not allow water depth to exceed $1.5 \mathrm{ft}$. at any point along the silt fence. 


\section{BMP: Straw Bale Barriers}

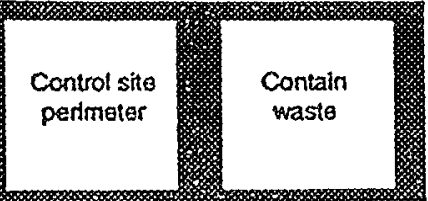

\section{GENERAL DESCRIPTION}

A straw bale barrier consists of straw bales placed end to end along a level contour in a shallow trench and staked to hold them in place.

\section{SUITABLE APPLICATIORS}

- Along the perimeter of the site or along streams and channels.

- Across swales with small catchments.

- Around temporary spoil areas.

- Below other small, cleared areas of one acre or less.

\section{UMITATIONS}

- Tend to rot and fall apart over extended periods of time. Constant maintenance is required.

- Suitable only for sheet flow on slopes of $2 \%$ or flatter.

- Not recommended for concentrated flow, inlet protection, channel flow, and live streams.

\section{INSTALLATION/APPLICATION GUIDELINES}

- Use primarily in areas where sheet or rill flow occurs.

- No more than $1 / 4$ acre per 100 feet of barrier should drain to the barrier.

- Install along a level contour.

- Place in a 4" deep trench.

- Backfill and compact the excavated soil on the upstream face of the barrier. Stake bale in place.

- Leave enough area (about 1200 sq. ft. per acre) behind the barrier for runoff to pond

\section{MAINTENANCE REQUIREMENTS}

- Inspect weekly and after each rain.

- Replace bales which have decomposed or whose bindings have broken.

- Remove sediment behind the barrier when sediment level reaches a depth of 6".

\section{COST CONSIDERATIONS}

\section{DESIGN LIFE}

3 months

\section{POLLUTANT REMOVAL EFFECTIVENESS}

Floatable materials

O Nutrients

Bacteria and viruses
Sediment

O Oil and grease

O Oxygen demanding substances
IMPLMENTATON REOUREMENTS

Capital Costs

O\&M Costs

Maintenance

Training 


\section{GENERAL INFORMATION}

A straw bale barrier consists of a series of secured anchored bales placed to intercept sediment-laden runoff from small drainage areas of disturbed soil. The barrier ponds runoff and allow sediment to settle. Straw bale barriers should not be used for extended periods of time because they tend to rot and fall apart.

Also, barriers placed in streams and drainageways wash out because of high runoff volumes and velocities. In addition, failure to properly stake and entrench the straw bale allows undercutting and end flow.

The straw bale barrier is used where there are no concentrations of water in a channel or drainageway, and where erosion would occur from sheet flow. These barriers are typically constructed below disturbed areas subject to sheet flow of runoff.

\section{Installation/Application Guidelines}

Straw bale barriers should be used for drainage areas no more than $1 / 4$ acre per $100^{\prime}$ of barrier length, with no more than $100 \mathrm{ft}$. upstream of any point along the barrier. The barrier should be placed along a level contour no greater than $2: 1$. When installed and maintained according to the guidelines on this fact sheet, straw bale barriers remove approximately $67 \%$ of the sediment transported in construction site runoff. This optimum efficiency can only be achieved through careful maintenance, with special attention to replacing rotted or broken bales. The barrier should be constructed on a level contour to prevent concentration of flow against a small portion of the barrier.

An effective straw bale barrier should be installed in the following manner:

1. Bales should be placed on the contour and in a row with ends tightly abutting the adjacent bales.

2. Leave area for runoff to pond upstream of the barrier by locating barrier away from the toe of slopes. This also provides access for maintenance.

3. Each bale should be embedded in the soil a minimum of $4^{\prime \prime}$ and placed so the bindings are horizontal. Bindings placed on soil will soon disintegrate and cause the barrier to fail.

4. Bales should be securely anchored in place by either two stakes or re-bars driven through the bale. The first stake in each bale should be driven toward the previously laid bale at an angle to force the bales together. Stakes should be driven flush with the bale.

5. Backfill and compact the excavated soil along the upstream face of the barrier.

6. Remove the barrier when it has served its usefulness so as not to block or impede storm flow or drainage. 


\section{Additional Information-Straw Bale Barrier}

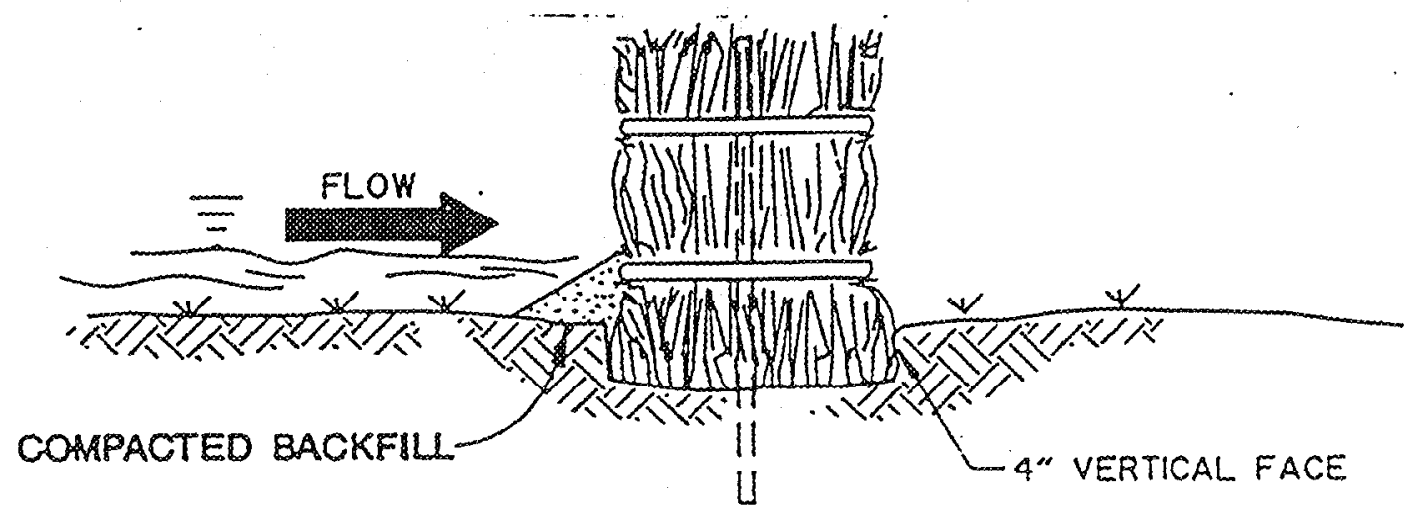

- PROMOTES ON SITE SEDIMENTATION BY CREATING A TEMPORARY PONO.

BEDDING DETAll

ANGLE FIRST STAKE TOWARO PREVIOUSLY LAID BALE

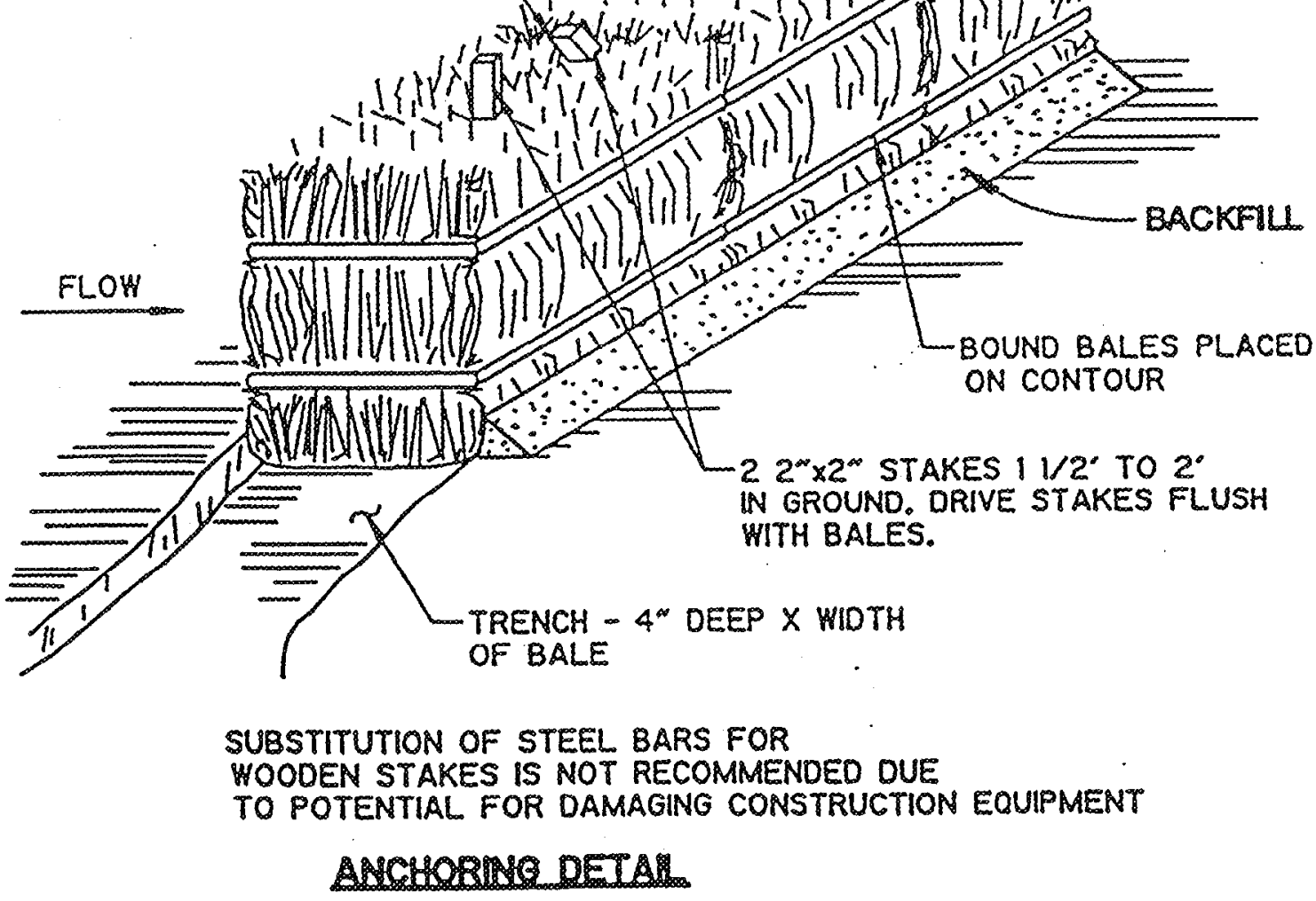

STRAW BALE BARRIERS 
A brush filter is composed of brush wrapped in filter cloth and anchored to the toe of the slope. A rock filter is made of rock $3 / 4^{\prime \prime}-3^{\prime \prime}$ in diameter and placed along a level contour where sheet flow may be detained and ponded, promoting sedimentation.

\section{SUITABLE APPLICATIONS}

- As check dams across mildly-sloped construction roads.

- Below the toe of slopes.

- Along the site peximeter.

- Along streams and channels.

- Around temporary spoil areas.

\section{LIMITATIONS}

- Rock berms may be difficult to remove.

- Removal problems limit their usefulness in landscaped areas.

\section{INSTALLATION/APPLICATION GUIDELNES}

- Use principally in areas where sheet or rill flow occurs.

- Install along a level contour.

- Drainage area should not exceed 5 acres.

\section{MAINTENANCE REQUIREMENTS}

- Inspect monthly and after each rainfall.

- If berm becomes damaged, reshape and replace lost/dislodged rock.

- Remove sediments when depth reaches $I^{\prime}$ or $1 / 3$ of berm height.

\section{COST CONSIDERATIONS}

- Brush filter: low to moderate cost if debris from on-site clearing and grubbing is used.

- Rock filter: Expensive, since off-site materials, hand construction and demolition/removal are usually required.

\section{DESIGN LIFE}

\section{POLUUANT REMOVAL EFFECTVENESS}

\section{Floatable materials}

O. Nutrients

Toxic chemicals
Sediment

Oil and grease

O) Other construction waste
IMPLEMENTATION REQUIREMENTS

Capital Costs

O\&M Costs

Maintenance

Training
ESC 13

ESC 21

ESC 28 


\section{Addirional Informotion Brush or Rock Filter}

\section{GENERAL INFORMATION \\ Rock Filfer}

A rock filter consists of open graded rock installed at the toe of a slope, along the perimeter of a developing or disturbed area, and as a checkdam across construction roads. Their purpose is to intercept sediment-laden runoff from disturbed areas of the site, allow the runoff to pond, promote sedimentation behind the filter, and slowly release the water as sheet flow. Advantages of the rock filters are that they may be less costly than other temporary barriers, and are relatively efficient at sediment removal.

Rock filters are appropriate where a temporary measure is needed to prevent sediments from entering right-of-ways of traffic areas such as near the toe of slopes, incorporated into temporary stabilized construction entrances (ESC 13), or at other locations along the construction site perimeter. Rock filters may also be used as check dams across one or more lanes of construction traffic temporary roads, or unsurfaced rights of way subject to construction traffic.

Installation/Application

Planning:

- Rock filters should be placed along a level contour to intercept sheet flow.

- Allow ample room for ponding, sedimentation, and access by sediment removal equipment between the berm and the toes of slopes.

- Flow through the filter should occur as sheet flow into an undisturbed or stabilized area.

- Installation in stream beds requires large rock, staking of woven wire sheathing, and daily inspection.

- If properly anchored, brush or rock filters may be used for sediment trapping and velocity reduction.

\section{Design \& Sizing Guidelines:}

The following design guidelines are commonly used to construct rock filters:

- In Non-Traffic Areas:

- Maximum flow-through rate per square foot of filter $=60 \mathrm{gpm}$

- Height=18" minimum

- Top width $=24^{\prime \prime}$ minimum

- Side slopes $=2: 1$ or flatter

- Woven wire sheathing (poultry netting) is recommended in areas of concentrated flow.

- The wire should be 1 " diameter hexagonal mesh, galvanized 20 gauge.

- Build the filter along on a level contour.

- Rock $=3 / 4-3$ " open graded for sheet flow, 3 to 5 inches open graded for concentrated flow.

- In Construction Traffic Areas:

- Height $=12^{\prime \prime}$ maximum

- Provide multiple filters in series, spaced as shown.

- Provide multiple filters in series, spaced as shown.

Every $300 \mathrm{ft}$ on slopes less than 5 percent

Every $200 \mathrm{ft}$ on slopes 5 to 10 percent

Every $100 \mathrm{ft}$ on slopes greater than 10 percent. 


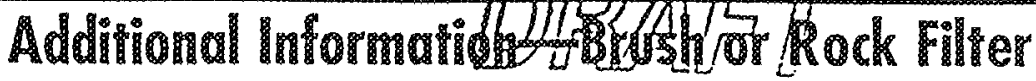

\section{Brush Filter}

Brush filters trap and filter sediments in a manner similar to other barriers (e.g., silt fence, straw bale barrier, rock filter), but have the advantage of being constructed from brush cleared from the site and usually disposed off-site at a cost.

\section{Installation/Application}

1. Stack the brush at the toe of a slope or along the perimeter of the site just outside the limits of clearing and grabbing. The brush may be stacked up to $15 \mathrm{ft}$ high and $15 \mathrm{ft}$ wide.

2. Construct a trench 1 to $3 \mathrm{ft}$ deep immediately upslope from the brush.

3. Place filter fabric over the brush filter and in the trench, extending 1 to $2 \mathrm{ft}$ upslope of the trench.

4. Backfill the trench with aggregate or compacted soil. The trench should be deep enough and backfill material sufficient to hold the barrier in place during a storm. 


\section{Additional Information-Brush or Rock Filter}

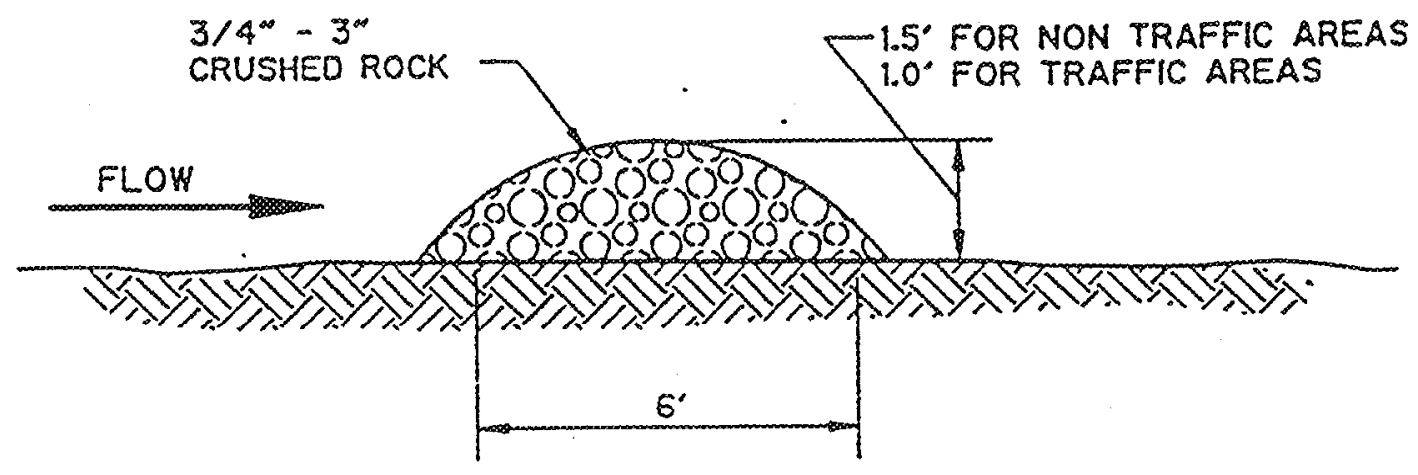

SECTION

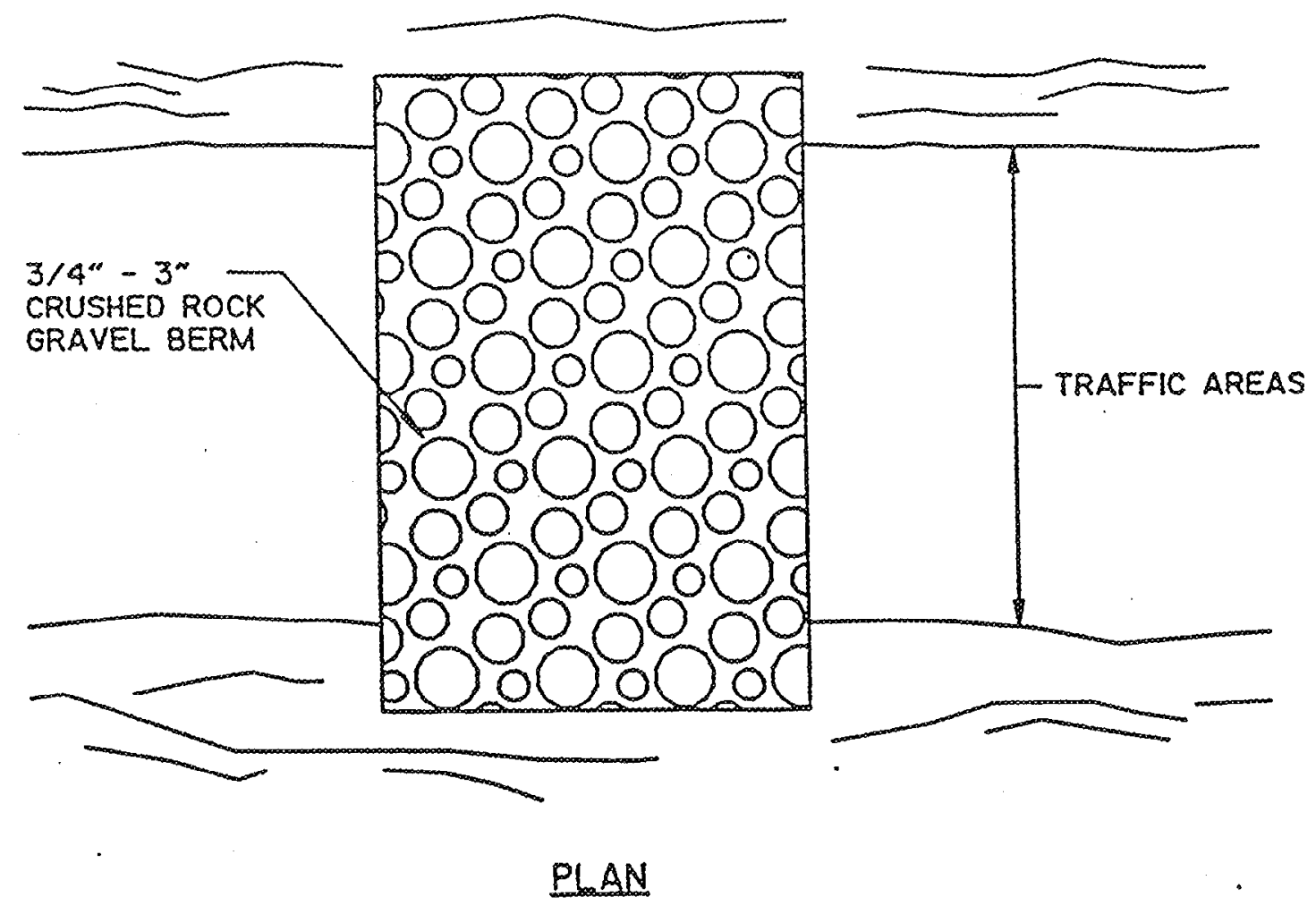

GRAVEL FILIER BERM 


\section{Appendix $\mathbb{C}$}

\section{Selected Calculations}


LLNL - National Ignition Facility

Storage Depth Per Sump Area For Different Rainfall Scenarios

\section{Input Data}

\section{Rainfall}

No. Days Total Precip Avg Precip

\begin{tabular}{|c|c|}
\hline (in) & (in/day) \\
\hline 4.02 & 4.02 \\
\hline 5.06 & 2.53 \\
\hline 5.70 & 1.90 \\
\hline 6.25 & 1.56 \\
\hline 6.77 & 1.35 \\
\hline 7.27 & 1.21 \\
\hline 8.18 & 1.02 \\
\hline 8.78 & 0.88 \\
\hline
\end{tabular}

\section{Sump Geometry}

Sump Elev Trib Area Storage Area

(ft)

611.50

(sf)

611.50

59,774

594.00

574.00

592.00

608.83
58,183

43,259

109,137

9,712

30,346 (st)

21,344 South

22,080 North

43,259 Tunnel

16,320 Target Bay with subareas not diked

3,600 OAB

$14,360 \mathrm{OAB}$

Sump 574.00 Target Bay with subareas diked off

$\begin{array}{llrl}574.00 & 49,997 & 16,320 \text { Retaining wall zone } \\ 586.75 & 23,767 & 7,843 \text { North } \\ 586.75 & 22,367 & 7,381 \text { South } \\ 579.25 & 19,126 & 6,312 \text { West }\end{array}$


Computation of Dike Elevations and Pumping Capacity

Note: The following depths do not include allowances for sediment or freeboard.

Storage Volume and Depth - Sump 611.50 South Laser Bay

No Days Rain Vol Depth Stored Dike Elev Pump Rate

\begin{tabular}{|c|c|c|c|c|}
\hline & (cf) & (ft) & $(f t)$ & (gpm) \\
\hline 1 & 20,024 & 0.94 & 612.44 & 104 Pumping Criteria \\
\hline 2 & 25,205 & 1.18 & 612.68 & \\
\hline 3 & 28,393 & 1.33 & 612.83 & \\
\hline 4 & 31,132 & 1.46 & 612.96 & \\
\hline 5 & 33,722 & 1.58 & 613.08 & Storage Criteria \\
\hline 6 & 36,213 & 1.70 & 613.20 & \\
\hline 8 & 40,746 & 1.91 & 613.41 & \\
\hline 10 & 43,735 & 2.05 & 613.55 & \\
\hline
\end{tabular}

Storage Volume and Depth - Sump 611.50 North Laser Bay

No Days Rain Vol Depth Stored Dike Elev Pump Rate

\begin{tabular}{|c|c|c|c|c|}
\hline & (cf) & (ft) & (ft) & (gpm) \\
\hline 1 & 19,491 & 0.88 & 612.38 & 101 Pumping Criteria \\
\hline 2 & 24,534 & 1.11 & 612.61 & \\
\hline 3 & 27,637 & 1.25 & 612.75 & \\
\hline 4 & 30,304 & 1.37 & 612.87 & \\
\hline 5 & 32,825 & 1.49 & 612.99 & Storage Criteria \\
\hline 6 & 35,249 & 1.60 & 613.10 & \\
\hline 8 & 39,661 & 1.80 & 613.30 & \\
\hline 10 & 42,571 & 1.93 & 613.43 & \\
\hline
\end{tabular}

Storage Volume and Depth - Sump 594.00 Tunnel

No Days Rain Vol Depth Stored Dike Elev Pump Rate

$\begin{array}{llll}(\mathrm{cf}) & (\mathrm{ft}) & (\mathrm{ft}) & (\mathrm{gpm})\end{array}$

$\begin{array}{rrrrr}1 & 14,492 & 0.34 & 594.34 & 75 \text { Pumping Criteria } \\ 2 & 18,241 & 0.42 & 594.42 & \\ 3 & 20,548 & 0.48 & 594.48 & \\ 4 & 22,531 & 0.52 & 594.52 & \\ 5 & 24,405 & 0.56 & 594.56 & \text { Storage Criteria } \\ 6 & 26,208 & 0.61 & 594.61 & \\ 8 & 29,488 & 0.68 & 594.68 & \\ 10 & 31,651 & 0.73 & 594.73 & \end{array}$


Storage Volume and Depth - Sump 574.00 Target Bay

No Days Rain Vol

(ct)

$\begin{array}{rr}1 & 36,561 \\ 2 & 46,019 \\ 3 & 51,840 \\ 4 & 56,842 \\ 5 & 61,571 \\ 6 & 66,119 \\ 8 & 74,395 \\ 10 & 79,852\end{array}$

Depth Stored

(fi)

2.24

2.82

3.18

3.48

3.77

4.05

4.56

4.89
Dike Elev Pump Rate

$\begin{array}{rr}(\mathrm{ft}) & (\mathrm{gpm}) \\ 576.24 & 190 \text { Pumping Criteria } \\ 576.82 & \\ 577.18 & \\ 577.48 & \\ 577.77 & \\ 578.05 & \\ 578.56 & \\ 578.89 & \end{array}$

Storage Volume and Depth - Sump \$92.50 Optics Assy. Bldg.

No Days Rain Vol Depth Stored Dike Elev Pump Rate

$\begin{array}{rrrrr} & (\mathrm{cf}) & (\mathrm{ft}) & (\mathrm{ft}) & (\mathrm{gpm}) \\ 1 & 3,254 & 0.90 & 592.90 & 17 \text { Pumping Criteria } \\ 2 & 4,095 & 1.14 & 593.14 & \\ 3 & 4,613 & 1.28 & 593.28 & \\ 4 & 5,058 & 1.41 & 593.41 & \\ 5 & 5,479 & 1.52 & 593.52 & \text { Storage Criteria } \\ 6 & 5,884 & 1.63 & 593.63 & \\ 8 & 6,620 & 1.84 & 593.84 & \\ 10 & 7,106 & 1.97 & 593.97 & \end{array}$

Storage Volume and Depth - Sump 608.83 Optics Assy. Bldg.

No Days Rain Vol Depth Stored Dike Elev Pump Rate

(cf)

(fi)

(ft) (gpm)

$\begin{array}{rrrrr}1 & 10,166 & 0.71 & 609.54 & 53 \text { Pumping Criteria } \\ 2 & 12,796 & 0.89 & 609.72 & \\ 3 & 14,414 & 1.00 & 609.83 & \\ 4 & 15,805 & 1.10 & 609.93 & \\ 5 & 17,120 & 1.19 & 610.02 & \text { Storage Criteria } \\ 6 & 18,385 & 1.28 & 610.11 & \\ 8 & 20,686 & 1.44 & 610.27 & \\ 10 & 22,203 & 1.55 & 610.38 & \end{array}$

Subareas of Sump 574.00 if Switchyards \& Diagnostics Separately Diked

Storage Volume and Depth - Sump 574.00 Target Bay

No Days Rain Vol Depth Stored Dike Elev Pump Rate

(cf)

16749

21082

23749

26040

28207

30290

34081

36581 (ft)

1.03

1.29

1.46

1.60

1.73

1.86

2.09

2.24 (ft) (gpm)

$\begin{array}{ll}575.03 & 87 \text { Pumping Criteria } \\ 575.29 & \\ 575.46 & \\ 575.60 & \\ 575.73 & \text { Storage Criteria } \\ 575.86 & \\ 576.09 & \\ 576.24 & \end{array}$


Storage Volume and Depth - Sump 586.75 North Switchyard

No Days Rain Vol Depth Stored Dike Elev Pump Rate

$\begin{array}{rrrrr} & (\mathrm{Cf}) & (\mathrm{ft}) & (\mathrm{ft}) & \text { (gpm) } \\ 1 & 7962 & 1.02 & 587.77 & 41 \text { Pumping Criteria } \\ 2 & 10022 & 1.28 & 588.03 & \\ 3 & 11289 & 1.44 & 588.19 & \\ 4 & 12379 & 1.58 & 588.33 & \\ 5 & 13409 & 1.71 & 588.46 & \text { Storage Criteria } \\ 6 & 14399 & 1.84 & 588.59 & \\ 8 & 16201 & 2.07 & 588.82 & \\ 10 & 17390 & 2.22 & 588.97 & \end{array}$

Storage Volume and Depth - Sump 586.75 South Switchyard

No Days Rain Vol Depth Stored Dike Elev Pump Rate

$\begin{array}{rrrrr} & (\mathrm{ct}) & (\mathrm{ft}) & (\mathrm{ft}) & (\mathrm{gpm}) \\ 1 & 7493 & 1.02 & 587.77 & 39 \text { Pumping Criteria } \\ 2 & 9431 & 1.28 & 588.03 & \\ 3 & 10624 & 1.44 & 588.19 & \\ 4 & 11649 & 1.58 & 588.33 & \\ 5 & 12619 & 1.71 & 588.46 & \text { Storage Criteria } \\ 6 & 13551 & 1.84 & 588.59 & \\ 8 & 15247 & 2.07 & 588.82 & \\ 10 & 16365 & 2.22 & 588.97 & \end{array}$

Storage Volume and Depth - Sump 579.25 West Diagnostics

No Days Rain Vol Depth Stored Dike Elev Pump Rate

$\begin{array}{rrrrr} & (\mathrm{cf}) & (\mathrm{ft}) & (\mathrm{ft}) & (\mathrm{gpm}) \\ 1 & 6407 & 1.02 & 580.27 & 33 \text { Pumping Criteria } \\ 2 & 8065 & 1.28 & 580.53 & \\ 3 & 9085 & 1.44 & 580.69 & \\ 4 & 9961 & 1.58 & 580.83 & \\ 5 & 10790 & 1.71 & 580.96 & \text { Storage Criteria } \\ 6 & 11587 & 1.84 & 581.09 & \\ 8 & 13038 & 2.07 & 581.32 & \\ 10 & 13994 & 2.22 & 581.47 & \end{array}$




\begin{tabular}{|c|c|c|c|c|}
\hline \multicolumn{5}{|c|}{$\begin{array}{l}\text { LLNL - National Ignition Facility } \\
\text { Construction Surface Water Control Schedule By Basin }\end{array}$} \\
\hline \multirow[b]{2}{*}{ Site Basin } & \multirow[b]{2}{*}{$\begin{array}{c}\text { Pump Rate } \\
\text { (gpm) }\end{array}$} & \multirow[b]{2}{*}{$\begin{array}{c}\text { Storage Depth } \\
\text { (ft) }\end{array}$} & \multicolumn{2}{|c|}{ Recommended } \\
\hline & & & $\begin{array}{c}\text { Dike Height } \\
(\mathrm{ft})\end{array}$ & $\begin{array}{c}\text { Pump Capacity } \\
\text { (gpm) }\end{array}$ \\
\hline Storage Volume and Depth - Sump 611.50 South Laser Bay & 104 & 1.58 & 2.6 & 100 \\
\hline Storage Volume and Depth - Sump 611.50 North Laser Bay & 101 & 1.49 & 2.5 & 100 \\
\hline Storage Volume and Depth - Sump 594.00 Tunnel & 75 & 0.56 & 2.6 & 75 \\
\hline Storage Volume and Depth - Sump 574.00 Target Bay & 87 & 1.73 & 2.7 & 90 \\
\hline Storage Volume and Depth - Sump 586.75 North Switchyard & 41 & 1.71 & 2.7 & 40 \\
\hline Storage Volume and Depth - Sump 586.75 South Switchyard & 39 & 1.71 & 2.7 & 40 \\
\hline Storage Volume and Depth - Sump 579.25 West Diagnostics & 33 & 1.71 & 2.7 & 40 \\
\hline Storage Volume and Depth - Sump 608.83 Optics Assy. Bidg. & 53 & 1.19 & 2.2 & 50 \\
\hline Storage Volume and Depth - Sump 592.50 Optics Assy. Bldg. & 17 & 1.52 & 2.5 & 20 \\
\hline Total Pumping Capacity & 534 & & & 535 \\
\hline
\end{tabular}

\section{Storage Areas Outside Excavations}

\begin{tabular}{|c|c|c|c|c|}
\hline Basin Name & $\begin{array}{c}\text { Storage Area } \\
\text { (sf) }\end{array}$ & $\begin{array}{c}\text { Available } \\
\text { Storage Depth } \\
\text { (ft) }\end{array}$ & $\begin{array}{c}\text { Storage Volume } \\
\text { Available (cf) }\end{array}$ & $\begin{array}{c}\text { Recommended } \\
\text { Discharge } \\
\text { Capacity (gpm) } \\
*\end{array}$ \\
\hline W Treatment Basin & 3,000 & 2 & 6,000 & 16 \\
\hline NW Treatment Basin & 6,000 & 3 & 18,000 & 47 \\
\hline No. Treatment Basin & 3,000 & 1 & 3,000 & 8 \\
\hline NE Treatment Basin & 9,600 & 1 & 9,600 & 25 \\
\hline Cooling Tower -610.83 & 3,150 & 4 & 12,348 & 32 \\
\hline Cooling Tower - 612.75 & 9,000 & 2 & 18,000 & 47 \\
\hline ETreatment Basin & 6,000 & 2 & 12,000 & 31 \\
\hline Total & & & 78,948 & \\
\hline ": Based on 2-day drawdown of available storage volume. & & $\begin{array}{r}\text { Equal to } \\
\text { Equivalent to }\end{array}$ & $\begin{array}{l}1.81 \\
3.15\end{array}$ & $\begin{array}{l}\text { ac-ft } \\
\text { inches rain }\end{array}$ \\
\hline
\end{tabular}


LLNL - National Ignition Facility

Disposal

Catch Basin Inlet Capacity

Curb inlet with back of curb opening $36^{\prime \prime}$ wido by 10 " high

Assume grate is blinded

Capacily when functioning as weir with water surface at top of opening

$\begin{array}{lr}\text { Length }= & 3.00 \mathrm{tt} \\ \text { Height }= & 0.83 \mathrm{ft} \\ \text { Coeft. }= & 3.27 \\ \text { Flow }= & 7.5 \mathrm{cs} \\ & 3.349 \mathrm{gpm}\end{array}$

Capacity when functioning as orifice with water surtace at top of opening

$\begin{array}{ll}\text { Area }= & 2.50 \mathrm{sf} \\ \text { Height }= & 0.56 \mathrm{ht} \text { above centrold } \\ \text { Coeft }= & 0.60 \mathrm{Ws} \\ \text { Flow }= & 9.0 \mathrm{cs}\end{array}$

Flow $=$

$027 \mathrm{gpm}$

Use lesser of the 2 above in combination with pipe barrel and inlet capacily to establish net inlel capacity.

Storm Draln Capacity

Pipe capacity based on Manning at full flow

\begin{tabular}{|c|c|c|c|c|c|c|c|c|c|c|c|c|c|c|}
\hline Pipe No. & $\begin{array}{c}\text { Thlet } \\
\text { Manholet } \\
\text { Catch } \\
\text { Basin No. }\end{array}$ & Dlam. (in) & $\begin{array}{c}\text { Manning's } \\
\text { ' } n \text { ' }\end{array}$ & Length (fi) & $\begin{array}{c}\text { Upper IE } \\
\text { (It) }\end{array}$ & $\begin{array}{c}\text { Lower IE } \\
\text { (II) }\end{array}$ & Slope & Area (sf) & Hyd R (it) & $\begin{array}{c}\text { Barrel } \\
\text { Capacity } \\
\text { (cts) }\end{array}$ & $\begin{array}{c}\text { Barrel } \\
\text { Capacily } \\
\text { (gpm) }\end{array}$ & $\begin{array}{l}\text { Available } \\
\text { Surcharge } \\
\text { Head (fi) }\end{array}$ & $\begin{array}{l}\text { Pipe Iniet } \\
\text { Capacity } \\
\text { (gpm) }\end{array}$ & $\begin{array}{c}\text { Net Inlet } \\
\text { Capacity } \\
\text { (gpm) }\end{array}$ \\
\hline 1 & $\mathrm{MH}-1$ & 48 & 0.013 & 158.6 & 600.46 & 599.65 & 0.0051 & 12.57 & 1.00 & 102.9 & 46.203 & 8.0 & & \\
\hline $\begin{array}{c}2 \\
2 \mathrm{~A}\end{array}$ & $\begin{array}{l}\mathrm{MH}-2 \\
\mathrm{CB}-5\end{array}$ & 48 & 0.013 & 295.0 & 599.65 & 598.13 & 0.0052 & $\begin{array}{r}12.57 \\
1.77\end{array}$ & $\begin{array}{l}1.00 \\
0.38\end{array}$ & $\begin{array}{r}103.4 \\
77\end{array}$ & $\begin{array}{r}46,405 \\
3,467\end{array}$ & 9.9 & & \\
\hline 3 & MH-3 & 48. & $\begin{array}{l}0.024 \\
0.013\end{array}$ & 46.3 & 601.50 & 600.65 & 0.0183 & $\begin{array}{r}1.77 \\
12.57\end{array}$ & $\begin{array}{l}1.20 \\
1.00\end{array}$ & 103.4 & $\begin{array}{r}3.467 \\
46.398\end{array}$ & $\begin{array}{r}7.3 \\
137\end{array}$ & 9.789 & 3,349 \\
\hline $3 A$ & CB-6 & 12 & 0.024 & 50.2 & 606.00 & 599.13 & 0.1369 & 0.79 & 0.25 & 7.2 & 3,212 & 4.1 & 3230 & 3212 \\
\hline 4 & MH.6 & 30 & 0.024 & 94.6 & 595.00 & 594.06 & 0.0099 & 4.91 & 0.63 & 22.2 & 9,967 & 6.7 & & \\
\hline 5 & MH.7 & 30 & 0.024 & 137.8 & 596.38 & 595.00 & 0.0100 & 4.91 & 0.63 & 22.3 & 10,005 & 8.0 & & \\
\hline 6 & (A) 1.8 & 24 & 0.024 & 240.5 & 601.00 & 596.63 & 0.0182 & 3.14 & 0.50 & 16.6 & 7,433 & 0.1 & & \\
\hline $6 A^{*}$ & CB-8 & 12 & 0.024 & 41.7 & 604.00 & 600.00 & 0.0959 & 0.79 & 0.25 & 6.0 & 2,688 & 4.0 & 3,198 & 2,688 \\
\hline $7^{*}$ & MH-9 & 24 & 0.024 & 170.4 & 604.97 & 603.27 & 0.0100 & 3.14 & 0.50 & 12.3 & 5,508 & 7.5 & & \\
\hline $7 A^{*}$ & CB-9 & 12 & 0.024 & 193.3 & 606.00 & 603.00 & 0.0155 & 0.79 & 0.25 & 2.4 & 1,082 & 5.2 & 3,684 & 1,082 \\
\hline 78 & CB-1 & 12 & 0.024 & 57.0 & 606.00 & 603.48 & 0.0442 & 0.79 & 0.25 & 4.1 & 1,826 & 4.5 & 3,374 & $\uparrow .826$ \\
\hline $7 \mathrm{C}$ & CB-2 & 12 & 0.024 & 34.6 & 607.00 & 604.97 & 0.0587 & 0.79 & 0.25 & 4.7 & 2.103 & 4.4 & 3,335 & 2,103 \\
\hline 8 & $M H-10$ & 24 & 0.024 & 317.7 & 607.20 & 604.97 & 0.0070 & 3.14 & 0.50 & 10.3 & 4,619 & 5.2 & & \\
\hline $8 \mathrm{~A}$ & CB-3 & 12 & 0.024 & 59.4 & 607.45 & 606.26 & 0.0200 & 0.79 & 0.25 & 2.7 & 1.228 & 3.9 & 3,135 & 1,228 \\
\hline 9 & $M H-11$ & 24 & 0.024 & 115.3 & 807.99 & 607.20 & 0.0069 & 3.14 & 0.50 & $\{0.2$ & 4,564 & 4.6 & & \\
\hline $9 A$ & $C B-13$ & 12 & 0.024 & 45.9 & 608.62 & 607.70 & 0.0201 & 0.79 & 0.25 & 2.7 & 1,230 & 3.2 & 2,805 & 1,230 \\
\hline 10 & $\mathrm{CB}-4$ & 24 & 0.024 & 216.9 & 609.51 & 607.99 & 0.0070 & 3.14 & 0.50 & 10.3 & 4,616 & 3.9 & & \\
\hline $10 \mathrm{~A}$ & $C B-10$ & 12 & 0.024 & 62.7 & 608.43 & 607.99 & 0.0070 & 0.79 & 0.25 & 1.6 & 727 & 3.4 & 2,876 & 727 \\
\hline 11 & $\mathrm{CB}-7$ & 12 & 0.024 & 70.8 & 605.00 & 597.90 & 0.1003 & 0.79 & 0.25 & 6.1 & 2,749 & 6.8 & 4,250 & 2.749 \\
\hline
\end{tabular}

- Flatter segment of pipe is analyzed. 
Appendix D

\section{Resumes of Key Personmel}


Richard L. Schaefer, P. E.

Director, Surface Water Management

- Education

- Registration

- Memberships
M.S. Civil Engineering - North Carolina State University

B.S. Civil Engineering - University of Michigan

Civil Engineer - Washington, Alaska, California

ASCE Water Resources Planning and Management Division:

- Urban Water Resources Committee (1994 - Present)

- Urban Water Resources Research Council (1995 - Present)

- Task Committee on Urban Drainage Rehabilitation Programs and Techniques (1991 - 93).

- Task Committee on Failure Diagnostics and Rehabilitation of Urban Drainage Infrastructure (1989 - 91).

APWA, Washington State Chapter, Stormwater Managers

Committee

\section{- Relevant Project Experience}

Rick Schaefer is an experienced project thanager in planning, design and construction of infrastructure projects and programs for public and private clients. He has demonstrated success in managing large, complex projects. Rick is a recognized leader in surface water management, and is extensively experienced in large diameter pipeline facilities and in general water and wastewater facilities.

\section{SURFACE WATER}

Snoqualmie Ridge Development - Snoqualmie, Washington

Managed design of stormwater control facilities for a 1,344-acre area planned to contain singlefamily and multi-family housing, a tournament golf course, office/business park campuses, schools, parks and open space. Designs included water quality treatment facilities, an earthfill dam, large diameter trunk lines, collector storm drains, and outfalls.

Design implemented the Master Drainage Plan (MDP) approved by the City of Snoqualmie and reviewed by King County. Facilities were designed to complement a tournament golf course and adjacent residential areas. Facilities include wetponds, ranging in size from 1.5 to 4.2 acre-fact, an earthfill dam impounding, a 52 acre-foot lake and irrigation supply reservoir, sand filter treatment systems, storm drain collection systems, hydraulic structures, trunk lines up to 60-inch in diameter, a $250 \mathrm{cfs}$ high-velocity HDPE pipeline, and energy-dissipating outfalls to stream channels and the Snoqualmie River. Temporary erosion and sedimentation control measures were also designed to construct these facilities and allow for grading of the golf course.

\section{Stormwater Utility Formation - City of Kirkland, Washington}

Managing utility formation process to fund surface water management program defined in recent Surface Water Master Plan. Assisted City in securing and administering Centennial Clean Water Fund grant to support the formation process. 
Richard L. Schaefer, P.E.

Director, Surface Water Management

Page 2

Stormwater Quality Management Plan - City of Anacortes, Washington

Managed preparation of grant-funded Comprehensive Stormwater Plan for the City and . adjoining areas of Skagit County. Plan establishes a prioritized capital improvement program, O\&M plan, water quality assessment, regulatory analysis, financing strategy, and proposed development standards and ordinances. This plan specifically addressed allocation of funding and improvement responsibilities between the City and new development.

Surface Water Utilities - Washington and Oregon

Assisted clients in the formation of user-fee-funded utilities to finance storm and surface water programs in the Cities of Edmonds and Puyallup, Washington and for the Unified Sewerage Agency, Oregon.

\section{Surface Water Master Plan - City of Kirkland, Washington}

Managed preparation of a Comprehensive Stormwater Management Plan, establishing a capital improvement program; O\&M guidelines, policies, ordinances and regulations; and funding strategy for program implementation.

\section{Surface Water Plan - City of SeaTac, Washington}

Managing comprehensive stormwater plan to include capital improvements and maintenance program, and operational and functional guidance for managing growth and development in the City's four watersheds.

\section{Regional Detention Facility - City of Everett, Washington}

Managed the rehabilitation of an earthfill dam regional detention facility on Pigeon Creek No. 2 using an innovative rock-fill embankment design. Project improved flood control, aesthetics, stability, and neighborhood safety.

\section{Burnt Bridge Creek Watershed Plan - Clark County, Washington}

Provided technical and policy review of planning assumptions, ordinances and watershed planning process for Clark County, Washington.

Smith, Smart, Hancock, Tabler and Schwenson - Seattle, Washington Expert witness support to litigation involving flooding, erosion and land use issues.

CNA Insurance - Seattle, Washington

Expert review of flooding claims.

King County Surface Water Management - Seattle, Washington

Completed 1990 King County Surface Water Design Manual drafts and conducted public review and workshops. Also managed consultant support to assist County in preparing the 1992 and subsequent revisions and updates to the manual, prepared issue papers, and supervised development of complementary software, BMP Manual, and training program.

\section{Development Review - Mount Vernon, Washington}

Performed review on behalf of the City of drainage, water quality and riparian elements of proposed development including golf course and 700 housing units. Sensitive site encompassed numerous wetlands and the headwaters of three watersheds supporting anadromous fisheries.

\section{Development Review - Kirkland, Washington}

Provided on-call review services to the City on stormwater aspects of development proposals. 
Richard L. Schaefer, P.E.

Director, Surface Water Management

Page 3

Surface Water Management - Public/Private Clients Throughout Washington and Oregon Prepared comprehensive surface water management plans for communities throughout Puget Sound and in Oregon. Completed hydraulic analyses, water quality studies and reviews of development proposals. Communities included: City of Anacortes, City of Edmonds, Snohomish County, City of Puyallup, King County, City of Kirkland, City of Mount Vernon, Pierce County, City of Port Angeles, and the Cities of Hillsborough and Gresham, Oregon.

\section{Leach Creek Regional Detention Facility Improvements - Tacoma, Washington}

Project Manager for 100 -cfs high-head stormwater pumping station, 42-inch diameter forcemain, dam spillway improvements, and wetland enhancements with telemetry-operated outlet structure to store and divery excess stormwater and control downstream flooding and stream channel erosion. Overall system performance is optimized using PLCs to monitor downstream flows, storage levels, and available receiving system capacity and to control release and diversion rates.

\section{Regional Stormwater Detention Facility - Snohomish County, Washington}

Project manager for design of award-winning regional stormwater detention facility integrating an earthfill dam, constructed wetland and park facility for Snohomish County, Washington.

\section{WATER}

Reservoir Study - Kent, Washington

Rehabilitation study of concrete reservoir for Kent, Washington.

Water System Evaluation - Los Alamos, New Mexico

Evaluation of water production, storage and transmission facilities for a sale agreement for the U.S. Department of Energy at Los Alamos National Laboratory, New Mexico.

\section{Water System Design - Ashland, Oregon}

Design of reservoir, pump station, and water transmission main for Ashland, Oregon.

Water System Design - Sitka, Alaska

Design of 5.3 miles of 30 - and 24-inch water transmission main for Sitka, Alaska.

Water System Design - Ketchikan, Alaska

Design of a 54-inch diameter above-grade penstock at the Ketchikan Lakes for Ketchikan Public Utilities.

\section{Comprehensive Water System Planning and Design - Washington and Alaska}

Completed comprehensive water system planning and design of distribution, pumping and reservoir improvements in Washington and Alaska. Communities include: Lakehaven Utility District, Covington Water District, King County Water District No. 111, City of Aberdeen, Washington and Wrangell, Alaska. 
Richard L. Schaefer, P.E.

Director, Surface Water Management

Page 4.

\section{WASTEWATER/CSO}

Wastewater Reuse Reservoir - Snoqualmie, Washington

Managed design of earth fill dam to impound Class A reclaimed wastewater and stormwater runoff. Facility serves as combined irrigation reservoir and stormwater treatment facility. Design and construction reviewed and permitted by Washington State Dam Safety Section..

Combined Sewer Overflow Regulator Design - Mount Vernon, Washington

Preliminary design of 6,000 feet of 60 -inch diameter interceptor sewer, overflow regulators and tributary sewer improvements to control combined sewer overflows in downtown Mount Vernon.

Wastewater Design and Construction Services - METRO, Seattle, Washington Design leader and construction services liaison for 12 miles of 96 -inch diameter wastewater effluent forcemain and 3.5 miles of water transmission main for Seattle METRO.

\section{Combined Sewer Overflow Control Project - Everett, Washington}

Project Manager for design of South Snohomish River combined sewer overflow control project, including 10,200 feet of 72-inch diameter low-head pressure interceptor sewer, 2,500 feet of 18- to 60-inch sewer, existing sewer rehabilitation, three regulators, lift station upgrade, and wastewater plant improvements for Everett, Washington.

\section{Combined Sewer Overflow Control Project - Everett, Washington}

Project Manager for design of North Snohomish River combined sewer overflow control project involving three river siphons, new regulators and sewers, rehabilitated siphon terminal structures, lift station upgrade, and wastewater plant modifications.

Wastewater System Improvements - Washington and Southeast Alaska

Wastewater pumping stations, forcemains and gravity sewers for cities, districts and regional agencies throughout Washington and Southeast Alaska. Communities include: City of

Aberdeen, Lakehaven Utility District, Pierce County Utilities, Sammamish Plateau Water and Sewer District, City of Edmonds, Washington and Wrangell, Alaska.

\section{Marine Outfall Replacement Design - Wrangell, Alaska}

Project Design Engineer for the replacement of 18-inch marine outfall line damaged by ship's anchor. Design resulted in floating new HDPE pipe into place and sinking into position to connect to upland structure and diffusion in 130 feet of water.

\section{PUBLICATIONS}

"Cost-Benefit Analysis of Urban Stormwater Controls," Integrated Water Resources Planning for the 21st Century, ASCE, 1995.

"Retrofitting a Regional Stormwater Facility," Urban Drainage Rehabilitation Programs and Techniques, ASCE, 1994.

"Local Agency Regulation: The Policies and Process of Surface Water Protection," Water Management in the '90s, ASCE, 1993. 
Richard L. Schaefer, P.E.

Director, Surface Water Management

Page 5

"The Role of Comprehensive Stormwater Planning in Reducing Drainage Infrastructure Failures," Proceedings of the 18th Annual Conference and Symposium, Water Resources Planning and Management and Urban Water Resources, ASCE, 1991.

"Retrofitting a Regional Stormwater Facility," Water Resources Infrastructure: Needs. Economics, and Financing. ASCE, 1990

"Low Cost GIS Application for Stormwater Management, "Water Resources Infrastructure: Needs, Economics, and Financing. ASCE, 1990.

"BAKWATR, Computations of Gradually Varied Flow," Advances in Engineering Software. CML Publications, England; October 1985.

"BAKWATR, Computations of Gradually Varied Flow," ASCE Specialty Conference on Computer Applications in Water Resources. ASCE, 1985.

"BAKWATR, Computations of Gradually Varied Flow," Proceedings of the Third Conference on Computing in Civil Fngineering. ASCE, 1984. 
James J. Lutz, P.E.

Senior Project Manager

- Education

M.S. Structural Engineering, U. of New So. Wales, Australia B.S. Civil Engineering, St. Louis University

Graduate Work, Carnegie-Mellon, U. of Missouri

- Registration

Civil Engineer, Alaska, Washington, California, Oregon, Hawaii, and Guam

Structural Engineer, Washington, Hawaii, and Guam

- Memberships

Structural Engineers Association of Washington

American Concrete Institute

American Welding Society

\section{- Relevant Project Experience}

Jim Lutz has over 29 years of civil and structural engineering experience. His project experience includes a spectrum of involvement in municipal and private projects ranging from feasibility studies and cost estimating through design and construction management. The following projects are examples of Mr. Lutz's expertise:

\section{Bridgeport Hydrologic Study - Douglas County, Washington}

Project manager for hydraulic analysis of numerous basins tributary to Bridgeport, snowmelt analysis, evaluation of existing storm drainage facilities.

Smith Draw Hydrologic Study - Douglas County, Washington

Project manager for hydrologic analysis of 12 square mile basin and evaluation of culvert and bridge alternatives.

City of Hydaburg, Alaska

Project engineer responsible for study, design, and construction of water and wastewater improvements. Design of two 200,000-gallon bolted steel reservoirs and chlorination equipment.

\section{City of Ketchikan, Alaska}

Sewer, water, drainage, and road design for North Point Higgins Subdivision. Approximately 300 acres in area; involved four miles of road.

\section{Schoenbar Bypass Road and Water Transmission Line - City of Ketchikan, Alaska} Designed this 1,500-foot road and 30" diameter ductile iron pipeline under a very tight schedule as an addendum after the Schoenbar Street Intertie was already advertised for construction. The street right-of-way descended by sharp curves through a steep rock cut to detine the pipeline route. The actual pipe geometry involved considerable three-dimensional analysis to select the fittings necessary to construct the pipe within the space available at an economical cost. A number of compound fittings were found essential. 
James J. Lutz, P.E.

Senior Project Manager

Page 2

The line terminates in tideland fill with working pressures of 140 psi; design was based on 250 psi. Since no real thrust anchorage could be provided at the terminus, the design employed a series of stepped reducers to absorb the thrust. Construction was completed in February 1987 within a few dollars of the amount estimated in the comprehensive plan in spite of the very minimal time allowed for design.

City of Srohomish, Washington

Foundation design, $2.7 \mathrm{mg}$ steel reservoir.

City of Blaine, Washington

Foundation design, $1.4 \mathrm{mg}$ steel Lincoln reservoir.

City of Blaine, Washington

Foundation design analysis, $1.2 \mathrm{mg}$ steel Harvey Road reservoir.

Municipal Wastewater Interception System - City of Wrangell, Alaska

Performed grant administration, prepared inflow/infiltration analysis, sewer system evaluation survey. Designed collection system, two pump stations, and saltwater outfall.

Carlanna Lake Disconnection Project - Ketchikan, Alaska

Designed 480,000 gallon reservoir and distribution modifications.

Ketchikan Wastewater Interceptor - City of Ketchikan, Alaska

Prepared inflow/infiltration analysis, sewer system evaluation survey, and plans and specifications for intertidal sewer interceptor system including saltwater outfall.

Forest Park Subdivision - City of Ketchikan, Alaska

Prepared comprehensive sewerage plan and designed collection and treatment systems and saltwater outfall.

5.0 mgd Municipal Wastewater Treatment Plant - City of Hilo, Hawaï Project manager, planning and design phase. Set up multiple contracts for design, CPM schedule, prepared grant and permit applications.

City of Saxman, Alaska

Project engineer responsible for studies, design, construction of water/wastewater improvements.

Liguan Terrace/Barrigada Heights, Guam

Design review, capacity analysis for 5-mgd wastewater pumping station.

City of Hydaburg, Alaska

Project engineer responsible for study, design, and construction of water and wastewater improvements.

City of Klawock, Alaska

Project engineer responsible for studies, design, and construction of water and wastewater improvements. 
James J. Lurz, P.E.

Senior Project Manager

Page 3

City of Metlakatla, Alaska

Project engineer responsible for inspection, design review, and logistics management for sewer and water system improvements.

Port West Shopping Center, Ketchikan, Alaska

Project manager for planning and structural design services, including $1 / 2$-acre graded area with riprap and 300 linear feet of oceanfront shore protection.

City of Ketchikan, Alaska

Designed road and utility improvements for Washington Park LID.

King County Parks Department - Snoqualmie, Washington

Project manager for design of repair to 48-inch culvert and 90-foot-high embankment along Preston/Snoqualmie Trail.

City of Ketchikan, Alaska

Walker Field, ballfield storm and underdrain system.

City of Saxman, Alaska

Totem Park and Long House, grading/drainage plan.

Ketchikan Gateway Borough School District - Ketchikan, Alaska

Houghtaling Elementary Athletic Field Development, Valley Park Elementary playground, regrading and drainage.

\section{Ketchikan Public Utilities - Ketchikan, Alaska}

Design of steel water main improvements along waterfront viaduct. Approximately 1500 feet of buried 30", 1500 feet of suspended 20", and 1500 feet of suspended 12 " mains.

\section{U.S. Navy - Amchitka, Alaska}

Contractor value engineering analysis of dock facility. Structural analysis of pile loads led to reduced pile size.

King County Parks Department, Snoqualmie, Washington

Preston/Snoqualmie Trail drainage restoration.

\section{STRUCTURAL EXPERIENCE}

Birmingham Street Stormwater Pumping Station, Seattle, Washington

Structural design of stormwater pumping station.

Snoqualmie Ridge 1040 Zone Reservoir, Snoqualmie, Washington

Structural design of $2.0 \mathrm{mg}$ prestressed concrete water reservoir.

Snoqualmie Ridge 1040 Pump Station, Snoqualmie, Washington

Structural design of concrete and masonry building, cranes and equipment supports for water pumping station. 
James J. Lutz, P.E.

Senior Project Manager

Page 4

Arlington Wastewater Treatment Plant, Arlington, Washington

Structural Design of headworks, post-tensioned concrete treatment tanks, and support buildings for $4.0 \mathrm{mg}$ wastewater treatment facility.

Bender Bridge - City of Lynden, Washington

Foundation design, installation specifications for precast concrete box culverts.

Public Utilities Administration, Guam

Electrical substation foundation and control building design, Macheche, Pulantat, and Tuman Substations.

Lakehaven Utility District - Federal Way, Washington

Pump Station Nos. 7 and 10. Structural modifications to reinforced concrete roof slabs to allow hatch additions.

Salmon Bay Vacuum Sewer System - City of Tacoma, Washington

Designed timber bulkhead and walkway design, pump station fender design.

\section{Wastewater Treatment Plant - City of Ketchikan, Alaska}

Performed Project management and structural design of 4.0 mgd primary treatment plant. The project included reinforced concrete tanks and building with precast concrete enclosure.

\section{Wastewater Treatment Plant - City of Oxnard, California}

Performed frame analysis and designed frame reinforcement and new supports for cement blender and storage silo addition to sludge dewatering facility.

\section{Boeing Process Assembly Building - Auburn, Washington}

Pipe supports for cooling water, nitrogen, and vacuum system. Building frame analysis to evaluate effect of new pipe loads.

\section{Southem Link Sewage Pump Station, Guam}

Building analysis and design of modifications, new vaults for upgrade of 5-MGD facility.

\section{0,000 Gallon Water Storage Reservoir, Grand Mound, Washington}

Foundation design for 42 ' diameter, $45^{\prime}$ high steel reservoir. The foundation was designed as a mat on an elastic foundation using the Finite-Element-Method, which resulted in significant cost savings compared to a trial design using rigid mat assumptions.

\section{Grand Mound Water Treatment Plan, Grand Mound, Washington}

Structural design of reinforced concrete oxidation ditch, including elevated slabs and adjacent anoxic mixing tanks for a $4.0 \mathrm{MG}$ facility. The oxidation ditch had to be designed for possible groundwater uplift as well as common walls with future plant expansions.

\section{6,000 Gallon Clarifier, North Bend, Washington}

Structural design of $80 \mathrm{ft}$ diameter, $14 \mathrm{ft}$ sidewall, reinforced concrete wastewater clarifier. Included design of base slab for groundwater pressure.

\section{Portola Valley, California}

Shop drawing reviews for bridge abutment and box culvert design. 
James J. Lutz, P.E.

Senior Project Manager

Page 5

Ketchikan, Alaska

Prepared foundation design for aircraft hangar at Peninsula Point.

\section{U.S. Coast Guard Base - Ketchikan, Alaska}

In 1979, cracks were observed in lower chords of several wood trusses supporting the roof of a gymnasium building at USCG Base, Ketchikan, Alaska. Temporary cable stays were installed on the trusses, and we were retained to investigate the failure and make recommendations regarding corrective action.

On site investigation revealed that the cracks had occurred at through members in the middle of gusset plates, but that gussets and bolted connections were intact. Performed a frame analysis and concluded that the failure was due to secondary stresses, but that collapse due to the strength remaining in the connection. Also determined that adjacent columns were underdesigned.

The Coast Guard ultimately performed major reconstruction of the building.

Ketchikan School District - Ketchikan, Alaska

Foundation design for warehouse.

Craig, Alaska

Design of foundation and floor slab alterations, E. C. Phillips fish company processing plant.

Spruce Mill Development Site - Ketchikan, Alaska

Project manager for evaluation of sheet pile bulkheads.

Whatcom Falls Reservoir No. 2 - City of Bellingham, Washington

Project manager and structural designer for 14 million gallon prestressed concrete water storage reservoir. Included design of internal hypalon baffle system for chlorine contact.

\section{Bear Valley Reservoir, Ketchikan Public Utilities - Ketchikan, Alaska}

Project management and structural design for 3 million gallon prestressed concrete water storage reservoir. Included internal partitions and baffles for chlorine contact.

\section{Jefferson Street Reservoir, Ketchikan Public Utilities - Ketchikan, Alaska}

Project management and structural design for 1.5 million gallon prestressed concrete water storage reservoir.

Dakin-Yew Pump Station - City of Bellingham, Washington

Structural design of two-story underground water pumping station. Work included design of concrete outlet structure from existing clearwell structure. Structural design of two 30,000-1b soda ash silos and building modifications to permit installation.

Derby Dam Improvements - City of Bellingham, Washington

Design of aluminum stoplog system to raise pond elevation at a trout hatchery. 
James J. Lutz, P.E.

Senior Project Manager

Page 6

Schoenbar Pipeline/Highlands Pump Station, Ketchikan Public Utilities - Ketchikan, AlaskaProject management and construction engineering for approximately one mile of 30- and 36 -inch water transmission pipeline and water pumping station. Structural design of valve vault addition to existing water treatment plant.

Boeing Autoclave - Frederickson, Washington

Design of water and nitrogen piping supports.

Lupine Meadows Water Reservoir, Roosevelt Water District - Snohomish, Washington Seismic analysis, performance specifications, and design reviews for $75 \mathrm{ft}$. $x 26 \mathrm{ft}$. diameter steel water storage reservoir.

Incinerator and Baling Facility - City of Ketchikan, Alaska

Structural design of foundations and floors for 15,000 s.f. incinerator facility.

\section{Lakemont Subdivision Bridges - Bellevue, Washington}

Abutment design and performance specifications for superstructures of four pedestrian and light traffic bridges to $100 \mathrm{ft}$. span including design of riprap and articulated block slope protection. Review of supplier design calculations.

Viewpoint Reservoir - Redmond, Washington

Supervised field inspection of post-tensioning anchorages on 1.5 million gallon $90 \mathrm{ft} . \times 110 \mathrm{ft}$. concrete reservoir. Condition inspection and seismic analysis.

Mariposa Pump Station and Reservoir - Mariposa, California

Foundation design for 1 million gallon steel water storage reservoir. Structural design of $50 \mathrm{ft}$. deep underground water pumping station building and adjacent electrical and surge tank vaults.

Wastewater Treatment Plant - City of Monroe, Washington

Performed structural design of $4.3 \mathrm{mgd}$ treatment plant. The $\$ 4.0$ million project includes structural additions for two primary clarifiers, secondary clarifiers, blower building, in-plant pump station, and anaerobic digester.

Water Storage Reservoir - Arlington, Washington

Foundation design, specifications, and superstructure design review for 2 million gallon steel water reservoir.

\section{STUDIES}

Swan Lake Interie EIS, Ketchikan, Alaska

Project manager for permit acquisition for 60 miles of electrical power line through the Tongass National Forest.

Sea-Tac International Airport, Washington

Technical review and value engineering for 1990 parking facility expansion.

City of Saxman, Alaska

Prepared Comprehensive Water and Sewer Plans. 
James J. Lutz, P.E.

Senior Project Manager

Page 7

U.S. Navy - Clark Air Force Base, Philippines

Quality control reviews and editing of water and sewer master plans.

State of Alaska

Performed preliminary site analyses and made recommendations for development and utility alternatives for the following Alaska State subdivisions: Hollis, Edna Bay, Olive Cove, Thoms Place, and Mountain Point.

\section{MUNICIPAL OUTFALL EXPERIENCE}

City of Wrangell, Alaska

Design of marine outfall for municipal wastewater treatment plant. Polyethylene.

Mountain Point Service Area - Ketchikan Gateway Borough, Alaska

Hydraulic and dispersion analysis, marine outfall for septic tank effluent collector, serving approximate population of 400 . Ductile iron.

Forest Park Subdivision - Ketchikan, Alaska

Hydraulic and dispersion analysis, design of marine outfall for Forest Park subdivision wastewater treatment plant. 100,000 gpd.

Point Higgins Subdivision - Ketchikan Gateway Borough, Alaska

Marine outfall location analysis (300 acres).

Metlakatla, Alaska

Construction supervision, marine outfall for wastewater lagoon effluent.

\section{TRANSPORTATION}

Swan Lake Intertie Access Road, Ketchikan, Alaska

Project Manager for design of 26 miles of forest road for electrical power project near Ketchikan, Alaska.

\section{Quartz Hill Mine Access Highway - Southeast Alaska}

EARTH TECH completed a road development project for the United States Borax and Chemical Corporation at Quartz Hill near Ketchikan, Alaska. The project involved the location, survey, layout, preliminary design of 24 miles, final design of 10 miles, and construction management of a mine access highway. Mr. Lutz provided the prcliminary design of the Wilson Arm route, which was prepared to AASHTO geometric standards for a two-lane highway for 75-ton offhighway trucks. The project included a 12 -foot shoulder for a tailings pipeline, which resulted in a 50-foot wide section. Environmentally sensitive areas required extensive coordination with the U.S. Forest Service. 
James J. Lutz, P.E.

Senior Project Manager

Page 8

FEMA

San Francisco, California (Loma Prieta Earthquake)

Damage surveys and cost estimates for FEMA water utility repairs. Included five 100,000 gallon water reservoirs, water treatment plant, swimming pool, water distribution system, 500,000-gallon water treatment plant clarifier, and other structures.

Craig Sewer System - City of Craig, Alaska

Designed Shelter Cove sewer extensions and lift station. Performed utility damage surveys for FEMA following winter storm.

\section{CEMETERY}

Sitka National Cemetery, Veteran's Administration, Sitka, Alaska

Planning, design, team management, site landscaping, memorial pavilion, paved access way, and public restrooms.

\section{OTHER EXPERIENCE}

\section{City of Bellingham, Washington}

Design, plans and specifications, and construction engineering for 48 " concrete cylinder pipe industrial waterline repair.

Ketchikan Gateway Borough, Alaska

Project manager and principal writer, waterfront development study.

Ketchikan Gateway Borough Airport Ferry Dock - Ketchikan, Alaska

Project manager for riprap repair and access upgrades.

City of Ketchikan, Alaska

Downtown waterfront master plan.

Guam Port Authority, Guam

Design management for fuel storage facilities.

Government of Guam - Department of Public Works, Guam

Design management for microdredging of Tumon Bay.

Alaska Wood Products Mill - Wrangell, Alaska

Designed tidelands dikes to contain solid waste.

Wrangell Port Facilities - Wrangell, Alaska

Prepared plans and specifications for Phase One tidelands landfill construction.

Hidden Falls Salmon Hatchery - Sitka, Alaska

Design of combination penstock and hatchery water supply line, including lake intake system. Intakes involved two $30^{\prime \prime}$ polyethylene floating lines, about $300^{\prime}$ long. Penstocks down steep mountain slope were parallel lines about $200^{\prime}$ long, $20^{\prime \prime}$ and $16^{\prime \prime}$. 
James J. Lutz, P.E.

Senior Project Manager

Page 9

Navy Arctic Research Lab - Barrow, Alaska

Performed construction inspection and contract administration for antenna field, communications building, aircraft hangar and parking apron.

Navy Arctic Research Lab - Barrow, Alaska

Performed design review and foundation inspection for a $20,000 \mathrm{~kW}$ diesel-electric power plant.

Chester Lake Dam - Metlakatla, Alaska

Design of approximately $3200^{\prime}$ of $20^{\prime \prime}$ steel penstock. Mountainous terrain, working pressure around $370 \mathrm{psi}$. Construction required use of helicopters.

Ketchikan Public Utilities - Ketchikan, Alaska

Project manager for preparation of Comprehensive Water Plan for Ketchikan.

Ketchikan Lakes Hydro Facility - Ketchikan, Alaska

Inspection of approximately $1500^{\circ}$ each of $48^{\prime \prime}$ and $54^{\prime \prime}$ wood stave penstock. Design of replacement bridge for both penstocks at stream crossing. Internal inspection of penstock turnels.

Tamgass Bay Fish Hatchery - Metlakatla, Alaska

Performed hydraulic evaluation study.

Whitman Lake Hatchery - Ketchikan, Alaska

PRV troubleshooting pipeline inspection and piping modification design.

City of Metlakatla, Alaska

Project Engineer responsible for inspection, design review, and logistics management for sewer and water system improvements.

Beaver Falls Hydroelectric Plant Penstocks - Ketchikan, Alaska

Condition inspection of trestle supports for about $1500^{\prime}$ to $30^{\prime \prime}$ steel penstock. 